\title{
Environmental sustainability of integrating the organic Rankin cycle with anaerobic digestion and combined heat and power generation
}

DOI:

10.1016/j.scitotenv.2018.12.190

\section{Document Version}

Accepted author manuscript

Link to publication record in Manchester Research Explorer

Citation for published version (APA):

Bacenetti, J., Fusi, A., \& Azapagic, A. (2018). Environmental sustainability of integrating the organic Rankin cycle with anaerobic digestion and combined heat and power generation. Science of the Total Environment. https://doi.org/10.1016/j.scitotenv.2018.12.190

\section{Published in:}

Science of the Total Environment

\section{Citing this paper}

Please note that where the full-text provided on Manchester Research Explorer is the Author Accepted Manuscript or Proof version this may differ from the final Published version. If citing, it is advised that you check and use the publisher's definitive version.

\section{General rights}

Copyright and moral rights for the publications made accessible in the Research Explorer are retained by the authors and/or other copyright owners and it is a condition of accessing publications that users recognise and abide by the legal requirements associated with these rights.

\section{Takedown policy}

If you believe that this document breaches copyright please refer to the University of Manchester's Takedown Procedures [http://man.ac.uk/04Y6Bo] or contact uml.scholarlycommunications@manchester.ac.uk providing relevant details, so we can investigate your claim.

\section{OPEN ACCESS}




\section{Accepted Manuscript}

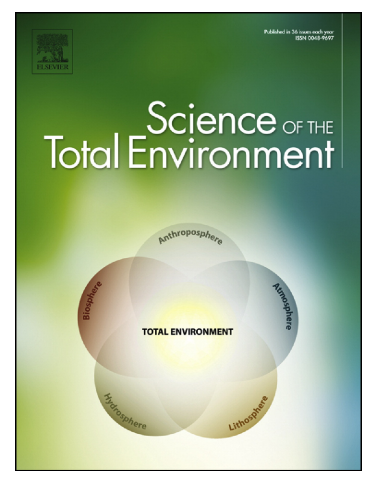

Jacopo Bacenetti, Alessandra Fusi, Adisa Azapagic

Environmental sustainability of integrating the organic Rankin cycle with anaerobic digestion and combined heat and power generation

PII: S0048-9697(18)35053-8

DOI: https://doi.org/10.1016/j.scitotenv.2018.12.190

Reference: STOTEN 30024

To appear in: Science of the Total Environment

Received date: 7 November 2018

Revised date:

11 December 2018

Accepted date:

12 December 2018

Please cite this article as: Jacopo Bacenetti, Alessandra Fusi, Adisa Azapagic , Environmental sustainability of integrating the organic Rankin cycle with anaerobic digestion and combined heat and power generation. Stoten (2018), https://doi.org/10.1016/ j.scitotenv.2018.12.190

This is a PDF file of an unedited manuscript that has been accepted for publication. As a service to our customers we are providing this early version of the manuscript. The manuscript will undergo copyediting, typesetting, and review of the resulting proof before it is published in its final form. Please note that during the production process errors may be discovered which could affect the content, and all legal disclaimers that apply to the journal pertain. 


\title{
Environmental sustainability of integrating the organic Rankin cycle with anaerobic digestion and combined heat and power generation
}

\author{
Jacopo Bacenetti ${ }^{1}$, Alessandra Fusi ${ }^{2}$, Adisa Azapagic ${ }^{2}$ \\ ${ }^{1}$ Department of Environmental Sciences and Policy, Università degli Studi di Milano, Via G. Celoria \\ 2, Milan, 20133, Italy. \\ ${ }^{2}$ Sustainable Industrial Systems, School of Chemical Engineering and Analytical Science, The \\ University of Manchester, Manchester, UK
}

* Corresponding author: adisa.azapagic@manchester.ac.uk

\begin{abstract}
Given the growing scarcity of primary energy resources, increasing the efficiency of energy conversion is one of the key challenges for optimising energy use. For this reason, low-grade or waste heat from various processes is becoming increasingly more attractive as an energy source. This study considers anaerobic digestion (AD) coupled with a combined heat and power plant $(\mathrm{CHP})$ as a source of low-grade heat for electricity generation utilising an organic Rankine cycle (ORC) system. The aim is to evaluate the environmental sustainability of such a system relative to the AD-CHP system without heat recovery. Ten real AD-CHP plants using cereal silage and animal slurry as feedstocks are considered for these purposes and their impacts have been estimated through life cycle assessment. The results suggest that systems with the ORC have lower impacts than those without it, but the average reductions are relatively small (1.6-5.8\%). However, for the smaller plants fed mainly with animal slurry, climate change increases significantly (up to 27 times). The reduction in impacts is greater for the bigger plants where the surplus heat available for the ORC is higher. The impacts from the ORC plant are insignificant, with its electrical efficiency and lifespan showing little effect on the results. Small slurry-fed plants without the ORC have lower environmental impacts than the bigger silage-fed plants fitted with an ORC system for nine out of 13 categories considered; climate change is up to 32 times lower. They are only slightly worse than the bigger plants with the ORC for ozone depletion and human toxicity due to the economies of scale. Therefore, while there are clear benefits of fitting an ORC system to an AD-CHP plant, greater benefits can still be achieved by utilising waste feedstocks, such as animal slurry, instead of fitting an ORC to a plant utilising cereal silage.
\end{abstract}

Keywords: biogas; biomass; climate change; energy; life cycle assessment; waste

\section{Introduction}

The European Union's policy framework for climate and energy aims to achieve a $40 \%$ cut in greenhouse gas emissions by 2030 on 1990 levels, a share of at least $27 \%$ of renewable energy and an improvement in energy efficiency of at least $27 \%$ (European Commission, 2014). In this context, and stimulated by subsidies, electricity generation from biogas produced by anaerobic digestion (AD) has grown rapidly in Europe over the past 20 years. Currently, Germany has the highest number of AD plants (about 9000) (German Biogas Association, 2016), followed by Italy (1800 plants) (Negri et al., 2014a; GSE, 2017). In 2016, the installed capacity reached $4166 \mathrm{MW}$ in Germany and $1406 \mathrm{MW}$ in Italy, generating 29.41 and 8.12 TWh of electricity, respectively. For Italy, this represents $2.56 \%$ of total annual electricity consumption (GSE, 2017).

Most AD plants in Europe are fed with cereal and grass silage and grain crops (Sieling et al., 2013; Bacenetti et al., 2014; Mauky et al., 2015). Cereal silage is favoured because of high specific biogas production (Gonzalez-Garcia et al., 2012), high energy density (Bacenetti et al., 2015b) and the ease of storage (Bacenetti and Fusi, 2015). AD of agricultural feedstocks has proved to be a viable solution for provision of renewable energy, in particular in rural areas where the energy is used locally (De Vries et al., 2011; 2012; Styles et al., 2016) and the heat cogenerated with electricity is fully exploited (Dressler et al., 2012; Bacenetti et al., 2013; Hahn et al., 2015). 
However, in most plants the use of cogenerated heat is not optimal, being limited to heating the digester with the rest either discarded or utilised only partially (Smolen, 2007). This results in low energy utilisation rates and waste of energy. Heat utilisation is problematic due to several reasons: (i) biogas plants, generally located at farms, are usually far from big and continuous thermal demands (e.g. hospitals, industries); (ii) distribution of heat is difficult and the construction of infrastructure requires considerable investments (Obi, 2015); (iii) there is an opposite seasonality between heat availability (maximum in summer) and thermal energy requirement in agricultural activities (maximum in winter; e.g. for stable and greenhouse heating and drying); and (iv) heat has low economic value.

The organic Rankine cycle (ORC) technology could represent an effective solution to the above issues by utilising waste heat to generate additional electricity. The ORC is a proven option for recovery of energy from low-temperature heat and an effective means of increasing the efficiency of energy conversion in AD plants (Drescher et al., 2005; Smolen, 2007). An ORC system is similar to a conventional Rankine cycle, but instead of water it uses an organic fluid; hence the name. The reason for using organic fluids is that their liquid-vapour phase change, or boiling point, occurs at a lower temperature than the water-steam phase change.

Since ORC installations generate additional power without requiring extra fuel, in addition to increasing the overall energy efficiency of the system, they also lead to lower emissions of pollutants per unit of energy (Vaja and Gambarotta, 2010). However, the environmental benefits of using ORC in AD plants have not been quantified so far. Instead, most studies have focused on environmental impacts of electricity generation from biogas produced by $A D$, highlighting that some impacts, such as eutrophication and acidification, can be significantly higher than from fossil-fuel electricity (Dressler et al., 2012; Lijò et al., 2014b; 2015). Only a few studies have assessed the environmental performance of waste heat utilisation from $A D$ plants, mainly as a substitute for fossil thermal energy (Meyer-Aurich et al., 2012; De Vries et al., 2012). However, none of the plants was equipped with an ORC system.

Therefore, the aim of this study is to evaluate the environmental sustainability and potential benefits from the utilisation of waste heat by an ORC system to generate electricity, in addition to that generated directly from biogas. Ten real biogas plants are considered cogenerating electricity and heat. The impacts are estimated on a life cycle basis, using life cycle assessment (LCA), as discussed in the next section.

\section{Methods}

The LCA methodology used in this study follows the ISO 14040/44 methodological guidelines (ISO, 2006a; 2006b). The goal of the study, the data and the assumptions are discussed below.

\subsection{Goal and scope of the study}

The goal of the study is to quantify potential environmental benefits or disadvantages of coupling $A D$ plants cogenerating heat and power (CHP) with the ORC technology to recover surplus (waste) heat and produce additional electricity. The ten AD-CHP plants considered in the study currently operate without an ORC system, hence the need to evaluate the environmental implications of its potential adoption. Therefore, the study is carried out in two steps:

i) first, the LCA impacts of the plants have been estimated without waste heat recovery via the ORC - this represents the current situation referred to here as the "AD-CHP system"; and

ii) it has then been assumed that these plants are fitted with an ORC system to estimate and compare the environmental impacts of the whole system with those of the AD-CHP system, with the aim of quantifying any potential benefits or drawbacks of waste heat utilisation. This is referred to as the "AD-CHP-ORC system".

The plants are situated in Italy and they utilise cereal silage and animal slurries, specifically maize, maize ear and triticale silage and pig and cattle slurry. The basis for analysis (the functional unit) is generation of $1 \mathrm{MWh}$ of electricity to be exported to the grid. 
The scope of the study is from 'cradle to grave', encompassing the following operations (Figure 1):

- production of cereal silage (where relevant), including cultivation, transport from fields to the farm $(1 \mathrm{~km})$ and the ensiling;

- slurry collection and delivery to the AD plants;

- production of biogas in the AD plants and its treatment (filtration, dehumidification and desulphurisation, carried out in a sand filter, a chiller and a scrubber, respectively);

- cogeneration of electricity and heat in the CHP plants;

- recovery of surplus heat from CHP to generate electricity in an ORC plant;

- storage (covered or open) of digestate and its application on land as fertiliser; and

- construction and decommissioning of AD, CHP and ORC plants.

These operations are described in more detail in the next sections.

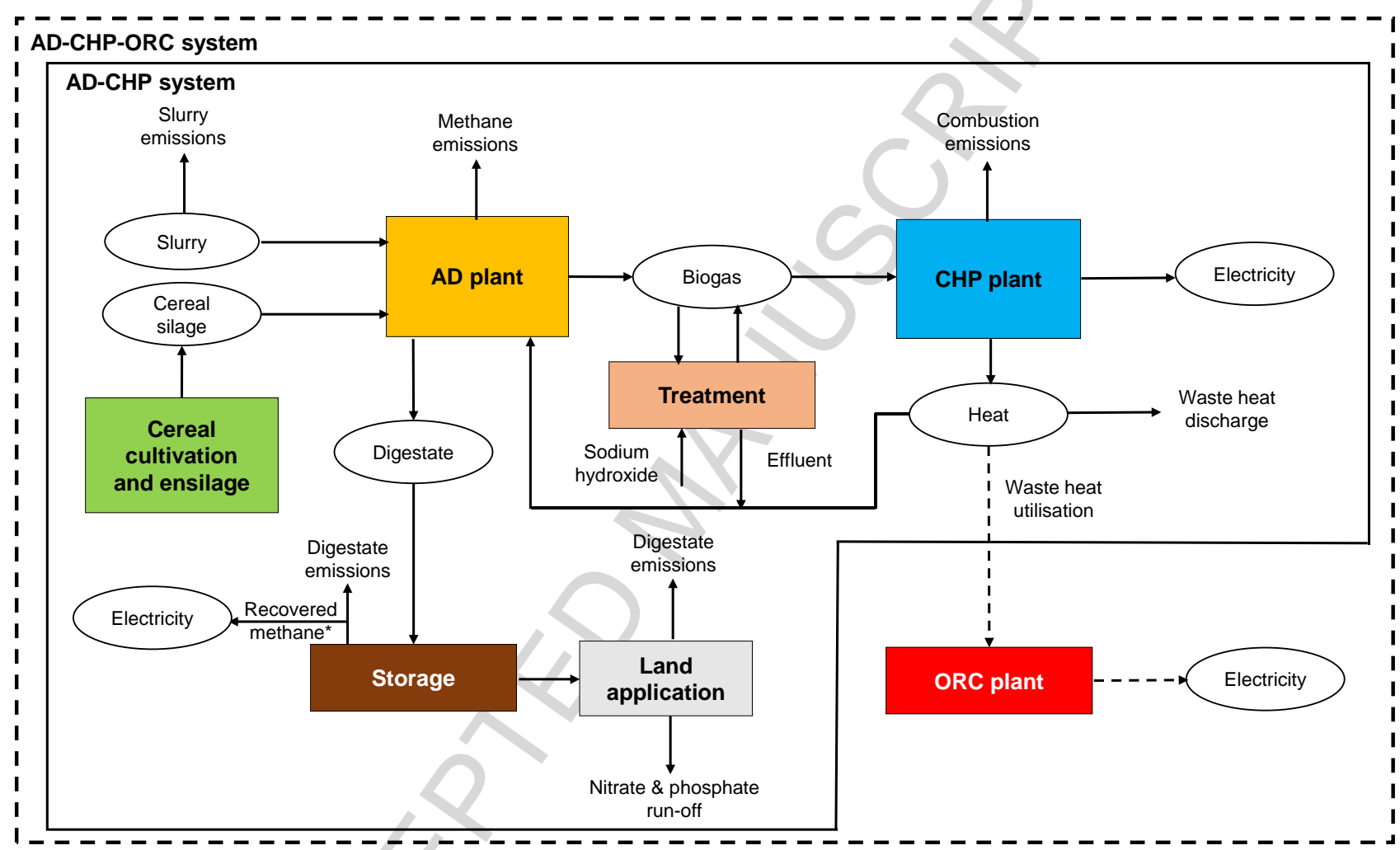

Figure 1. System boundaries considered in the study for the AD-CHP and AD-CHP-ORC systems.

$\left[{ }^{*}\right.$ Methane is only recovered from closed storage of digestate. No environmental impacts are considered for the pig and cattle slurry as they represent waste. The solid line system boundary refers to the AD-CHP system and the dashed line to the AD-CHP-ORC system.]

\subsection{System description}

\subsubsection{The AD-CHP system}

As indicated in Figure 1, the AD-CHP system comprises the collection of slurry, cultivation of cereals, their digestion in an AD plant to produce biogas, followed by its subsequent treatment and utilisation in a CHP plant to generate heat and electricity.

Anaerobic digestion is carried out at mesophilic conditions in continuously stirred digesters fed with the biomass every $90 \mathrm{~min}$. Depending on the plant considered, the dry matter content in the digester ranges from 5.2 to $9.3 \%$, and the organic loading rate from 0.45 to $3.99 \mathrm{~kg} / \mathrm{day}^{3} \mathrm{~m}^{3}$. The produced biogas is stored at the top of the digesters in a gasometer dome with a spherical cap. The digestate is pumped from the bottom of the digesters and stored in open or covered tanks. 
After dehumidification and desulphurisation (with $\mathrm{NaOH}$ ), the biogas is fed into the CHP plant to generate electricity and heat. Electricity is sold to the national grid while some of the heat is used for heating the digesters and the surplus is discharged as waste heat.

\subsubsection{The AD-CHP-ORC system}

In addition to the activities considered in the AD-CHP system, the AD-CHP-ORC system includes recovery of surplus (waste) heat to generate electricity. The surplus heat from the CHP can be recovered at two points: from the cooling circuit of the $\mathrm{CHP}$ engine (hot water at $80-90^{\circ} \mathrm{C}$ ) and from the engine's exhaust gases $\left(450-550^{\circ} \mathrm{C}\right)$. The former is used to heat the digesters, supplemented by a portion of the latter, depending on the climatic conditions. Consequently, the amount of surplus thermal energy that could be recovered via an ORC system to generate electricity varies over the year. The ORC turbines have been sized so as to be able to operate at their nominal power during winter without affecting the digester's heating. The following section explains how this heat has been calculated to determine the appropriate capacity of the ORC installation.

\subsubsection{Estimation of the ORC heat recovery potential}

The electricity and heat flows between the AD, CHP and ORC plants are summarised in Figure 2 and their estimation is detailed below.

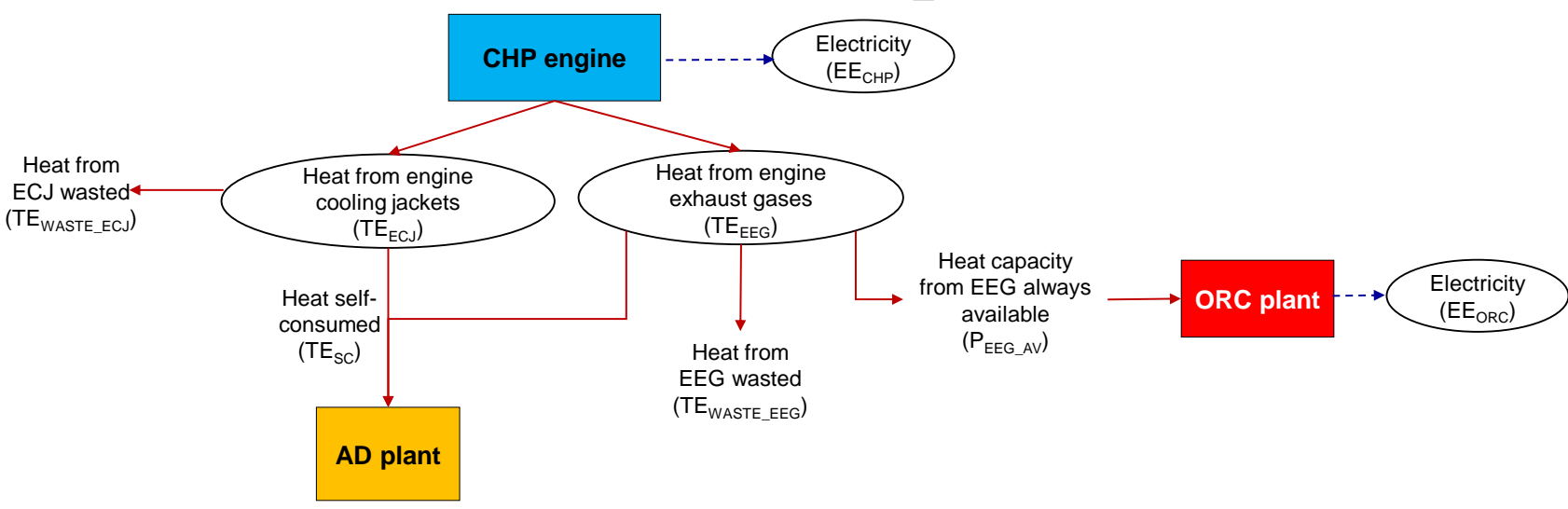

Figure 2. Energy flows in the AD, CHP and ORC plants

[ECJ: energy cooling jackets; EEG: engine exhaust gases; TE: thermal energy; SC: self-consumption. P: thermal capacity]

The power produced by the CHP depends on its electrical capacity and the annual operating time, as follows:

$\mathrm{EE}_{\mathrm{CHP}}=\mathrm{P}_{\mathrm{EE} \_\mathrm{CHP}} \times \mathrm{W}_{\mathrm{t}}$

where:

$\mathrm{EE}_{\mathrm{CHP}} \quad$ electricity produced by the CHP plant ( $\mathrm{kWh} /$ year)

$\mathrm{P}_{\mathrm{EE} \_\mathrm{CHP}} \quad$ electrical capacity of the CHP plant $(\mathrm{kW})$

$\mathrm{W}_{\mathrm{t}} \quad$ annual operating time of the CHP plant (h/year).

The thermal energy produced by the CHP is available at low enthalpy as hot water $\left(70-80^{\circ} \mathrm{C}\right)$ in the engine cooling jacket (ECJ) and at medium-high enthalpy at the engine exhaust gases (EEG). Considering the annual operating time of the CHP, they can be calculate according to eqns. (2) and (3)

$T E_{E C J}=P_{T E E C J} \times W_{t}$

$T E_{E E G}=P_{T E \_E E G} \times W_{t}$ 
where:

$T E_{\mathrm{ECJ}}$

$P_{\text {TE_ECJ }}$

heat recovered from the engine cooling jacket ( $\mathrm{kWh} /$ year)

$T E_{E E G}$ thermal capacity of the hot water in the engine cooling jacket $(\mathrm{kW})$

$P_{\text {TE_EEG }}$ heat recovered from the engine exhaust gases ( $\mathrm{kWh} /$ year) thermal capacity of the engine exhaust gases $(\mathrm{kW})$.

The total thermal capacity of the CHP plant is equal to:

$\mathrm{P}_{\mathrm{TET}}=\mathrm{P}_{\mathrm{TE} \_\mathrm{ECJ}}+\mathrm{P}_{\mathrm{TE} \_E E G}$

where:

$\mathrm{P}_{\mathrm{TET}} \quad$ total heat capacity of the CHP plant $(\mathrm{kW})$

The thermal energy consumed to heat the digesters ("self-consumed" energy) depends of digester characteristics, the feed and the air temperature. It can be calculated as:

$\mathrm{TE}_{\mathrm{SC}}=\sum_{i}^{12} T E_{S C_{-} i}$

where:

$\mathrm{TE}_{\mathrm{SC}}$ total self-consumed heat for digesters (kWh/year)

$\mathrm{TE}_{\mathrm{SC} \_} i$ self-consumed heat for digesters in month $i(\mathrm{kWh})$

i month in a year (-)

12 total number of months in a year (-).

Self-consumed heat $T E_{S C_{-} i}$ is estimated as:

$\mathrm{TE}_{\mathrm{SC}_{-} i}=\left[\left(\mathrm{M}_{\mathrm{BIO}} \times \Delta \mathrm{t} \times \mathrm{S}_{\mathrm{h}}\right) \times(1+\mathrm{k})\right] \times \mathrm{d}$

$M_{\mathrm{BIO}} \quad$ mass of the feedstocks in the digester (t/day)

$\Delta \mathrm{t} \quad$ difference between the air temperature and the temperature in the digester $\left({ }^{\circ} \mathrm{C}\right)$

$\mathrm{S}_{\mathrm{h}} \quad$ specific heat of the feedstock $\left(1.162 \mathrm{kWh} / \mathrm{t}{ }^{\circ} \mathrm{C}\right.$, including the specific heat of water, given the moisture content in all the feedstock of $>65 \%$ )

$k$ coefficient of thermal dispersion (proportion of thermal energy used to heat the feedstock in the digester that is lost) (\%).

d number of days in month $i$ (days).

Depending on the air temperature, a different share of the thermal energy produced by the ECJ and EEG is consumed and, consequently, a different amount is wasted or available. The wasted heat from the ECJ and EEG can be calculated according to eqns. (6) and (7):

$T E_{\text {WASTE_ECJ }}=T E_{E C J}-T E_{S C ;}$ if $T E_{E C J}-T E_{S C}<0$, then $T E_{\text {WASTE_ECJ }}=0$

$\mathrm{TE}_{\mathrm{WASTE}_{-} \mathrm{EEG}}=\mathrm{TE}_{\mathrm{EEG}}-\left(\mathrm{EE}_{\mathrm{ORC}} / \eta_{\mathrm{ORC}}\right)$

where:

TE WASTE_ECJ $_{\text {_ }}$ waste heat recovered by the engine cooling jackets $(\mathrm{kWh} /$ year)

TE WASTE_EEG $_{\text {WEste }}$ wast recovered from engine exhaust gases ( $\mathrm{kWh} /$ year)

$\mathrm{EE}_{\mathrm{ORC}} \quad$ electricity produced by the ORC plant (kWh/year)

П

The thermal energy available from the EEG is equal to:

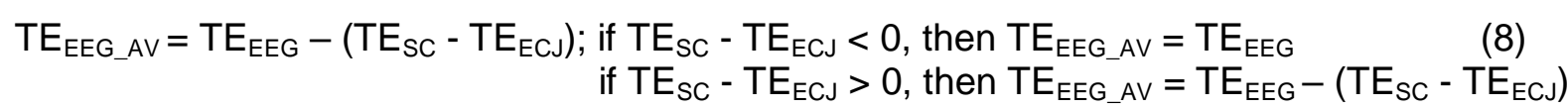

where:

$\mathrm{TE}_{\mathrm{EEG} \_\mathrm{AV}} \quad$ heat available from the engine exhaust gases ( $\mathrm{kWh} / \mathrm{year}$ ) 
The electricity produced by the ORC can be calculate as:

$E_{\mathrm{ORC}}=\mathrm{P}_{\mathrm{EE}_{-} \mathrm{ORC}} \times \mathrm{W}_{\mathrm{t}}$

where:

$\mathrm{P}_{\mathrm{EE} \_\mathrm{ORC}} \quad$ electrical capacity of the ORC plant $(\mathrm{kW})$

The electrical capacity of the ORC, calculated according to eqn. (10), depends on the electrical efficiency of the ORC and the thermal capacity of heat always available from the EEG:

$P_{E E \_O R C}=P_{E E G \_A V} \times \eta_{O R C}$

where:

$P_{E E G \_A V} \quad$ thermal capacity of the heat always available from the EEG during the year $(\mathrm{kW})$

The sizing of the $\mathrm{ORC}$ considering $\mathrm{P}_{\mathrm{EEG} \_\mathrm{Av}}$ allows the $\mathrm{ORC}$ to run at its maximum capacity during all operating hours; therefore:

$\mathrm{P}_{\mathrm{SC} \_ \text {max }}=\mathrm{TE}_{\mathrm{SC} \_ \text {max }} / \mathrm{Wt}_{\text {max }} ; \quad$ if $\mathrm{P}_{\mathrm{ECJ}}>\mathrm{P}_{\mathrm{SC} \_ \text {max }}$, then $\mathrm{P}_{\mathrm{EEG} \_\mathrm{AV}}=\mathrm{P}_{\mathrm{EEG}}$

where:

$$
\text { if } P_{E C J}<P_{S_{-} \_ \text {max }} \text { then } P_{E E G \_A V}=P_{E E G}-\left(P_{S C \_ \text {max }}-P_{E C J}\right)
$$

$\mathrm{P}_{\mathrm{SC}_{-} \max } \quad$ maximum thermal capacity of self-consumed heat $(\mathrm{kW})$

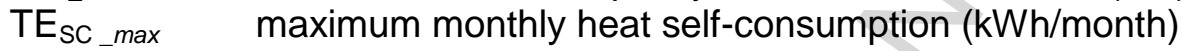

$\mathrm{W}_{\mathrm{t} \_\max } \quad$ operating time in the month with $\mathrm{TE}_{\mathrm{SC} \_ \text {max }}(\mathrm{h})$.

\subsection{Inventory data}

The inventory data are summarised in Table 1 and discussed in the following sections. The plant data have been collected over a full year to account for operational variations across different seasons.

\subsubsection{AD feedstock production}

As indicated in Table 1, three types of silage are used in AD plants: maize, maize ear and triticale. Life cycle inventory ( $\mathrm{LCl}$ ) data on their production have been obtained from the literature (Gonzalez-Garcia et al., 2013; Negri et al., 2014b; Bacenetti et al., 2015a). Data on the cereal yields have been collected through surveys and interviews of the farmers who are also the owners of the biogas plants. The background LCl data have been sourced from Ecoinvent 3 (Weidema et al., 2013) but have been modified to match the characteristics of the farm machinery used for cereal silage production in Italy, based on information in Bodria et al. (2006).

Air, water and soil emissions from pesticide used in the cultivation of cereals have been calculated based on Margni et al. (2002) and Audsley et al. (1997), assuming that $85 \%$ of active pesticide compounds applied remains in the soil, $5 \%$ in the plant and $10 \%$ is emitted into the atmosphere. Furthermore, $10 \%$ of the applied dose is lost as a run-off from the soil into the water. Emissions of nitrous oxide, ammonia (from volatilisation), nitrate (from leaching) and phosphate (from run-off) during fertiliser application (digestate and urea (for feedstock cultivation)) have been carried out according to Brentrup et al. (2000) which enables consideration of the rainfall, wind, soil characteristics and nutrient balance.

The transport and packaging of pesticides and fertilisers used to produce the cereals are not included within the system boundary because of a lack of data. However, this does not compromise the robustness of the study as some other studies found their contribution to be negligible (e.g. Cellura et al., 2012). No change in the overall soil carbon content has been assumed because the fields were previously dedicated to cereal cultivation and hence no land use change occurred in the past 20 years. In addition to the silage, some plants also use cattle or pig slurry. No environmental impacts are considered for the slurries as they represent waste. 
Table 1. Design and operating data for the AD, CHP and ORC plants considered in this study ${ }^{\mathrm{a}}$.

\begin{tabular}{|c|c|c|c|c|c|c|c|c|c|c|c|}
\hline Parameter & Unit & $\begin{array}{l}\text { Plant } \\
\text { A }\end{array}$ & B & C & D & E & $\mathbf{F}$ & G & $\mathbf{H}$ & I & $\mathbf{J}$ \\
\hline \multicolumn{12}{|l|}{$A D$ plant } \\
\hline Maize silage & t/year & 16,293 & 16,566 & 10,740 & 10,948 & 0 & 10,806 & 0 & 3374 & 0 & 1044 \\
\hline Triticale silage & t/year & 0 & 0 & 8055 & 6843 & 11,143 & 0 & 0 & 2025 & 0 & 0 \\
\hline Maize ear silage & t/year & 0 & 0 & 0 & 0 & 0 & 0 & 21,137 & 0 & 0 & 0 \\
\hline Pig slurry & t/year & 16,958 & 0 & 10,069 & 0 & 0 & 0 & 0 & 14,172 & 4878 & 16,700 \\
\hline Cattle slurry & t/year & 0 & 26,719 & 0 & 0 & 20,260 & 0 & 11,273 & 0 & 19,513 & 0 \\
\hline Water & t/year & 0 & 3563 & 6713 & 8553 & 0 & 0 & 0 & 0 & 0 & 0 \\
\hline Temperature in digesters & ${ }^{\circ} \mathrm{C}$ & 40 & 40 & 51 & 41 & 40 & 53 & 39 & 40.5 & 40 & 40 \\
\hline Methane emissions & kg/year & 27,265 & 29,172 & 27,541 & 24,798 & 17,610 & 15,807 & 9524 & 9187 & 4608 & 3315 \\
\hline Liquid fraction of digestate & t/year & 43,225 & 46,313 & 43,631 & 44,476 & 43,897 & 33,658 & 5284 & 0 & 0 & 0 \\
\hline Digestate storage & - & Open & Covered & Covered & Covered & Open & Covered & Open & Covered & Open & Open \\
\hline $\mathrm{NaOH}$ for biogas treatment ${ }^{9}$ & $\mathrm{~kg} / \mathrm{year}$ & 470.0 & 524.2 & 494.9 & 434.3 & 285.7 & 263.1 & 148.5 & 148.8 & 68.9 & 49.6 \\
\hline \multicolumn{12}{|l|}{ CHP plant } \\
\hline Electrical capacity ( $\left.\mathrm{P}_{\mathrm{EE} \_\mathrm{CHP}}\right)$ & $\mathrm{kW}_{\mathrm{el}}$ & 998 & 998 & 999 & 861 & 598 & 505 & 298 & 300 & 150 & 101 \\
\hline Thermal capacity ( $\left.\mathrm{P}_{\mathrm{TE}} \mathrm{EEG}\right)$ & $\mathrm{kW}_{\text {th }}$ & 1098 & 1097 & 1099 & 999 & 730 & 631 & 390 & 393 & 210 & 141 \\
\hline $\begin{array}{l}\text { Thermal capacity of water in the engine cooling jacket } \\
\left(P_{T E ~ E C J)}\right.\end{array}$ & $\mathrm{kW}_{\text {th }}$ & 533 & 532 & 533 & 484 & 382 & 306 & 189 & 191 & 188 & 120 \\
\hline $\begin{array}{l}\text { Thermal capacity recovered by engine exhaust gases } \\
\left(P_{T E} E E G\right)\end{array}$ & $\mathrm{kW}_{\text {th }}$ & 566 & 565 & 566 & 514 & 376 & 325 & 201 & 202 & 108 & 73 \\
\hline Operating time $\left(\mathrm{W}_{\mathrm{t}}\right)$ & h/year & 7980 & 8550 & 8055 & 8211 & 8104 & 8503 & 8455 & 8098 & 7805 & 8350 \\
\hline Electricity generation ( $\mathrm{EE}_{\mathrm{CHP}}$ ) & $\mathrm{MWh}_{\mathrm{e}} / \mathrm{yea}$ & 7964 & 8533 & 8047 & 7070 & 4846 & 4294 & 2520 & 2429 & 1171 & 843 \\
\hline Self-consumption of electricity ${ }^{\mathrm{g}}$ (EESC) & $\mathrm{MWh}_{\mathrm{el}} /$ year & 716.93 & 767.06 & 659.80 & 664.38 & 445.57 & 446.24 & 224.04 & 206.39 & 128.54 & 92.47 \\
\hline Heat generation ( $\left.T E_{E C J}+T E_{E E G}\right)$ & MWh/year & 6762 & 6822 & 5626 & 6363 & 4053 & 3732 & 2736 & 2455 & 826 & 531 \\
\hline Maximum thermal energy demand for digester & $\mathrm{kW}_{\text {th }}$ & 405 & 451 & 416 & 339 & 382 & 180 & 106 & 140 & 188 & 120 \\
\hline \multicolumn{12}{|l|}{ TESC max) } \\
\hline Self-consumed heat for digesters (TESC) & MWh/year & 2403.5 & 2862.4 & 2490.9 & 2068.5 & 2301.6 & 1136.2 & 662.8 & 844.9 & 1092.5 & 742.9 \\
\hline Thermal capacity of heat from EEG always avail & $\mathrm{kW}_{\text {th }}$ & 566 & 565 & 566 & 514 & 347 & 325 & 201 & 202 & 22 & 21 \\
\hline \multicolumn{12}{|l|}{ ORC (PEEG AV) } \\
\hline Lubricating oil ${ }^{9}$ & $\mathrm{~kg} /$ year & 2150.8 & 2301.2 & 2172.5 & 1908.3 & 1307.6 & 1158.5 & 679.7 & 655.6 & 315.5 & 227.0 \\
\hline \multicolumn{12}{|l|}{ Emissions from CHP } \\
\hline NOx & kg/year & 446.88 & 478.13 & 451.40 & 396.51 & 271.70 & 240.71 & 141.22 & 136.22 & 65.55 & 47.16 \\
\hline NMVOC $^{a}$ & $\mathrm{~kg} /$ year & 22.30 & 23.86 & 22.53 & 19.79 & 13.56 & 12.01 & 7.05 & 6.80 & 3.27 & 2.35 \\
\hline $\mathrm{CH}_{4}$ & kg/year & 960.68 & 1027.86 & 970.39 & 852.39 & 584.08 & 517.47 & 303.58 & 292.83 & 140.92 & 101.38 \\
\hline $\mathrm{CO}$ & $\mathrm{kg} /$ year & 685.86 & 733.82 & 692.79 & 608.55 & 416.99 & 369.44 & 216.74 & 209.06 & 100.61 & 72.38 \\
\hline $\mathrm{N}_{2} \mathrm{O}$ & kg/year & 3.54 & 3.78 & 3.57 & 3.14 & 2.15 & 1.91 & 1.12 & 1.08 & 0.52 & 0.37 \\
\hline As & g/year & 87.62 & 93.75 & 88.51 & 77.75 & 53.27 & 47.20 & 27.69 & 26.71 & 12.85 & 9.25 \\
\hline $\mathrm{Cd}$ & g/year & 7.97 & 8.52 & 8.05 & 7.07 & 4.84 & 4.29 & 2.52 & 2.43 & 1.17 & 0.84 \\
\hline Co & g/year & 462.02 & 494.33 & 466.69 & 409.94 & 280.90 & 248.87 & 146.00 & 140.83 & 67.77 & 48.76 \\
\hline $\mathrm{Cr}$ & g/year & 398.29 & 426.14 & 402.32 & 353.40 & 242.16 & 214.54 & 125.86 & 121.40 & 58.43 & 42.03 \\
\hline
\end{tabular}


ACCEPTED MANUSCRIIPT

\begin{tabular}{|c|c|c|c|c|c|c|c|c|c|c|c|}
\hline $\mathrm{Mn}$ & g/year & 422.19 & 451.71 & 426.46 & 374.60 & 256.69 & 227.41 & 133.42 & 128.69 & 61.93 & 44.55 \\
\hline $\mathrm{Ni}$ & g/year & 509.81 & 545.47 & 514.97 & 452.35 & 309.96 & 274.61 & 161.11 & 155.40 & 74.79 & 53.80 \\
\hline $\mathrm{Pb}$ & g/year & 7.97 & 8.52 & 8.05 & 7.07 & 4.84 & 4.29 & 2.52 & 2.43 & 1.17 & 0.84 \\
\hline $\mathrm{Sb}$ & g/year & 262.87 & 281.26 & 265.53 & 233.24 & 159.82 & 141.60 & 83.07 & 80.13 & 38.56 & 27.74 \\
\hline Se & g/year & 462.02 & 494.33 & 466.69 & 409.94 & 280.90 & 248.87 & 146.00 & 140.83 & 67.77 & 48.76 \\
\hline V & kg/year & 87.62 & 93.75 & 88.51 & 77.75 & 53.27 & 47.20 & 27.69 & 26.71 & 12.85 & 9.25 \\
\hline $\mathrm{Zn}$ & & 8.74 & 9.35 & 8.83 & 7.75 & 5.31 & 4.71 & 2.76 & 2.66 & 1.28 & 0.92 \\
\hline \multicolumn{12}{|l|}{ ORC plant } \\
\hline Electrical capacity ( $\left.\mathrm{P}_{\mathrm{EE}} \mathrm{ORC}\right)$ & $\mathrm{kW}_{\mathrm{el}}$ & 55 & 55 & 55 & 50 & 35 & 30 & 20 & 20 & $n / a^{d}$ & $n / a^{d}$ \\
\hline Self-consumption of electricity ${ }^{\dagger}$ & $\mathrm{MWh}_{\mathrm{e}} /$ year & 87.8 & 94.1 & 88.6 & 82.1 & 56.7 & 51.0 & 33.8 & 32.4 & $n / a^{d}$ & $n / a^{d}$ \\
\hline
\end{tabular}

Self-consumption of

$\mathrm{MWh}_{\mathrm{e}} / \mathrm{yea}$

87.8

94.1

$82.6 \quad 82.1$

${ }^{b}$ Electricity produced by recovering methane from the covered digestate storage.

${ }^{c}$ In the coldest month (January)

${ }^{d}$ n/a: Not applicable, consistent with Schoulz et al. (2007).

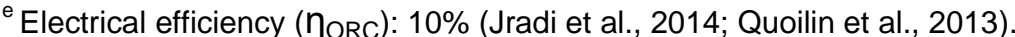

Equal to $20 \%$ of generated electricity.

${ }^{g}$ Consumables. 


\subsubsection{AD, CHP and ORC plants}

The characteristics of the AD, CHP and ORC plants are detailed in Table 1.

$A D$ plants: The volume of the AD digesters across the ten plants ranges from 4200 to $11,900 \mathrm{~m}^{3}$. The digesters are manufactured from iron-reinforced concrete and have external insulation made of expanded polyurethane.

Data on feedstock requirements, consumption of electricity and heat, electricity generation have been obtained from the plant owners (farmers). The biogas production from the AD plants has been calculated based on the studies of Fiala (2012), Negri et al. (2014a; 2014b) and Bacenetti et al. (2015a) who determined the biogas production potentials of different feedstocks. Fugitive methane emissions from the AD plant have been assumed at $2 \%$, consistent with previous studies (Dressler et al., 2012; Lijò et al., 2014a; 2014b; 2015; Bacenetti and Fiala, 2015).

The digestate from all the plants is used as fertiliser. Its application leads to emissions of ammonia and nitrous oxide to air as well as nitrate leachate and run-off of phosphates into water. The latter has been estimated using the method proposed by Nemecek and Kägi (2007) while the former three have been calculated according to Brentrup et al. (2000).

Before the AD plants were installed, these farms used to use pig or cattle slurry and, therefore, the digestate replaces these inputs. Both the digestate and the slurry are stored in open or covered tanks, during which they emit methane, ammonia and nitrous oxide. However, these emissions from digestate are lower than from slurry storage (Amon et al., 2006; Wang et al., 2014) so that the $A D$ systems have been credited for their avoidance, following the approach developed by Fusi et al. (2016). Furthermore, covered storage of digestate reduces the emissions by $80 \%$ compared to the open tanks. The methane emissions from covered tanks are recovered and fed to the CHP system to produce additional electricity.

The lifetime of the AD plants is assumed to be 20 years (Nemecek and Kägi, 2007).

CHP plants: The CHP plant consists of a container with an internal combustion engine (ICE) (1500 $\mathrm{rpm}$ ) and a generator (1235 kVA, frequency $50 \mathrm{~Hz}$, voltage $400 \mathrm{~V}$ ). The installed electrical capacity of the CHP plants varies from 101 to $999 \mathrm{~kW}$ (Table 1). The emissions from the CHP plants have been calculated based on NERI (2010). For the CHP plants, the assumed lifespan is eight years (Fiala et al., 2012).

$O R C$ plants: It is assumed that the ORC installation comprises a heat exchanger for heat recovery from the engine exhaust gases, an expander, a micro-turbine coupled with an electricity generator, a regenerator-condenser and tubes and pipes for thermal oil distribution within the cycle. As shown in Table 1, the estimated electrical capacity of the ORC plants ranges from 20-55 kW, assuming the operating temperature of $>150^{\circ} \mathrm{C}$, net electrical efficiency of $10 \%$ and self-consumption of electricity of $20 \%$ (Schulz et al., 2007; Obi, 2015). Note that plants I and J are not suitable for an ORC installation as they produce only $22 \mathrm{~kW}_{\text {th }}$ of surplus heat (Table 1) which would require an ORC system smaller than $3 \mathrm{~kW}_{\text {el }}$ (based on the net electrical efficiency of 10\%). The largest ORC systems available commercially have the installed electrical capacity of $10 \mathrm{~kW}$ (Schulz et al., 2007). The assumed lifespan is 20 years (Bini et al., 2010).

At the end of their useful lifetime, the construction materials of the AD, CHP and ORC plants are assumed to be recycled, except for scrap copper, plastic materials and spent perfluropentane which are incinerated.

The background data for the construction materials, their transport and landfilling have been sourced from Ecoinvent 3 (Weidema et al., 2013). Since the data for construction materials for the $A D, C H P$ and ORC plants in Ecoinvent correspond to different sizes $\left(800 \mathrm{~m}^{3}\right.$ for the $A D, 160 \mathrm{~kW}_{\mathrm{el}}$ for the CHP and $1400 \mathrm{~kW}_{\text {th }}$ for the ORC plants), the environmental impacts from their manufacture have been estimated by scaling up or down to the sizes of the AD, CHP and ORC plants considered in this study. This has been carried out following the approach used for scaling up the 
costs of process plants (Coulson et al., 1993), adapted for estimation of environmental impacts from their construction (Whiting and Azapagic, 2014; Fusi et al., 2016):

$E_{2}=E_{1} \cdot\left(C_{2} / C_{1}\right)^{0.6}$

where:

$E_{2} \quad$ environmental impacts of the larger plant

$E_{1} \quad$ environmental impacts of the smaller plant

$C_{2} \quad$ capacity of the larger plant

$C_{1} \quad$ capacity of the smaller plant

0.6 scaling factor.

\subsection{Impact assessment}

The systems considered here have been modelled using SimaPro LCA software 8.05 and the impacts estimated according to the ReCiPe method (Goedkoop, 2009). The following 13 impacts are considered: climate change, ozone depletion, terrestrial acidification, freshwater and marine eutrophication, human toxicity, photochemical oxidant and particulate matter formation, terrestrial, freshwater and marine eco-toxicity, metal and fossil depletion.

\section{Results}

The environmental impacts are first presented for the eight plants with an ORC installation (ADCHP-ORC systems). This is followed by their comparison with the plants without it (AD-CHP systems) and discussion of any potential benefits or drawbacks of waste heat utilisation through the ORC. The effect of different influencing parameters on the impacts is also taking into account their values across the plants considered. Finally, a sensitivity analysis is carried out to gauge the robustness of some of the key data and assumptions.

As mentioned earlier, the remaining two plants ( $\mathrm{I}$ and $\mathrm{J}$ ) are too small for an ORC installation and hence the discussion in the next section is limited to Plants $\mathrm{A}-\mathrm{H}$.

\subsection{Impacts of AD-CHP-ORC systems}

The results in Figure $\mathbf{3}$ and Table $\mathbf{S 1}$ in the Supplementary Information (SI) suggest that electricity generated by Plant B is environmentally the best option among the plants considered, largely because it utilises slurry rather than cereal silage as a feedstock and has covered digestate storage. The plants with the highest impacts vary across the categories. Electricity generation by Plant $A$ is the worst option for climate change, terrestrial and freshwater eco-toxicity, while Plant $E$ has the highest ozone depletion, freshwater eutrophication, photochemical oxidants and particulate matter formation. The maximum values for terrestrial acidification and human toxicity are found for Plant $D$. The reason for the poor performance of Plant $A$ is the high impacts of maize silage while for Plants $E$ and $D$ this is due to the low yield of triticale. Plant $G$ causes the greatest marine eutrophication and Plant $\mathrm{H}$ biggest marine eco-toxicity and metal depletion. These findings are discussed below for each impact in turn.

Climate change (CC): This impact ranges from -40.34 to $408.59 \mathrm{~kg} \mathrm{CO}$ eq./MWh with Plant $\mathrm{B}$ being the best and Plant $A$ the worst option (Figure 3a). The net negative carbon emissions for Plant $B$ are due to the credits for the avoided traditional slurry storage, which instead is used to produce biogas. Generally, plants fed predominantly by animal slurry $(B, G, H)$ have much lower $\mathrm{CC}(-40.34$ to $78.5 \mathrm{~kg} \mathrm{CO}$ eq./MWh) than the rest of the plants using mainly silage (164.3-408.59 $\mathrm{kg} \mathrm{CO}$ eq./MWh).

For Plants $A, E$ and $G$, the impact is mainly due to the methane and nitrogen dioxide emissions associated with the storage of digestate in open tanks (285 $\mathrm{kg} \mathrm{CO}_{2}$ eq./MWh). For Plants $\mathrm{B}, \mathrm{C}, \mathrm{D}$, $\mathrm{F}$ and $\mathrm{H}$, the emissions from the digestate are reduced due to the covering of the storage tanks; as a result, the major contributor to the impact from these plants is the cultivation of cereals. Covering the storage tanks reduces the overall impact on average by $21 \%$. 


\section{ACCEPTED MANUSCRIPT}

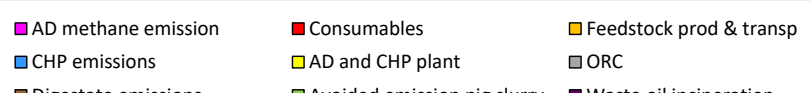

$\begin{array}{lll}\square \text { AD methane emission } & \text { घConsumables } & \square \text { Feedstock prod \& transp } \\ \square C H P \text { emissions } & \square A D \text { and CHP plant } & \square O R C\end{array}$

$\square A D$ methane emission
$\square C H P$ emissions

Consumables

$\square \mathrm{AD}$ and CHP plant

$\square$ Feedstock prod \& trans

$\square$ Digestate emissions

$\square$ Avoided emission pig slurry $\quad$ Waste oil incineration

$\square$ Digestate emissions $\quad \square$ Avoided emission pig slurry $\square$ Waste oil incineration

$\square$ Digestate emissions $\quad \square$ Avoided emission pig slurry $\square$ Waste oil incineration

口igestate emissions $\quad \square$ Avoided emission pig slurry $\square$ Waste oil incineration
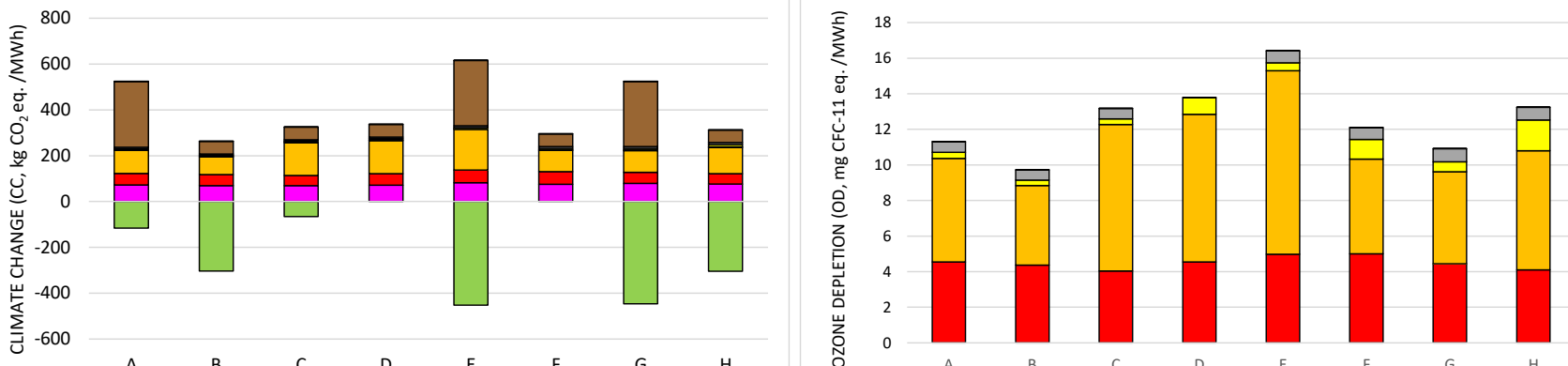

a) Climate change

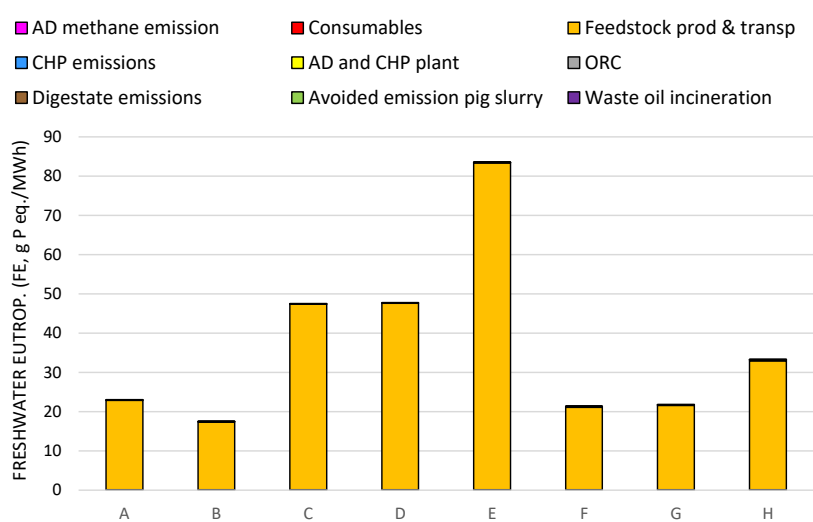

\section{b) Ozone depletion}

$\begin{array}{lll}\square \text { AD methane emission } & \square \text { Consumables } & \text { 口Feedstock prod \& trans } \\ \square C H P \text { emissions } & \square A D \text { and CHP plant } & \text { पORC }\end{array}$

$\square \mathrm{ORC}$

$\sum^{7}$

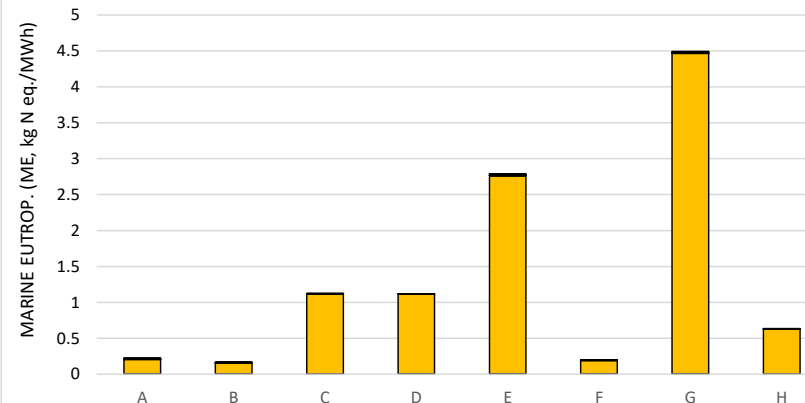

d) Freshwater eutrophication

$\begin{array}{lll}\square \text { AD methane emission } & \square \text { Consumables } & \square \text { Feedstock prod \& transp } \\ \square C H P \text { emissions } & \square A D \text { and CHP plant } & \square O R C\end{array}$

\section{e) Marine eutrophication}

$\begin{array}{lll}\square \text { AD methane emission } & \square \text { Consumables } & \text { पFeedstock prod \& transp } \\ \square C H P \text { emissions } & \square A D \text { and CHP plant } & \text { 口 ORC }\end{array}$

- Digestate emissions $\quad \square$ Avoided emission pig slurry $\quad$ E Waste oil incineration

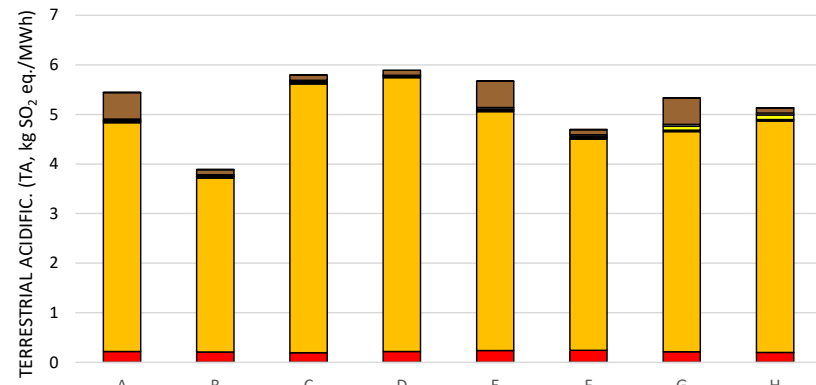

C) Terrestrial acidification

$\square$ AD methane emission $\quad$ CConsumables $\quad$ FFeedstock prod \& transp $\square C H P$ emissions $\quad \square A D$ and $C H P$ plant $\quad$ घORC $\square$ Digestate emissions $\quad$ aAvoided emission pig slurry $\quad$ QWaste oil incineration

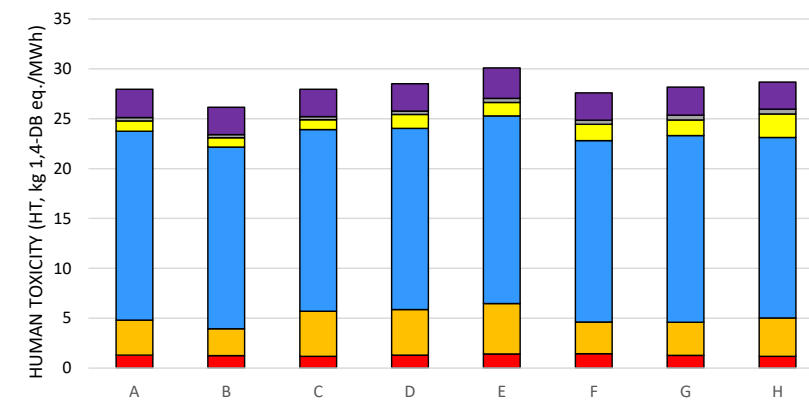

f) Human toxicity
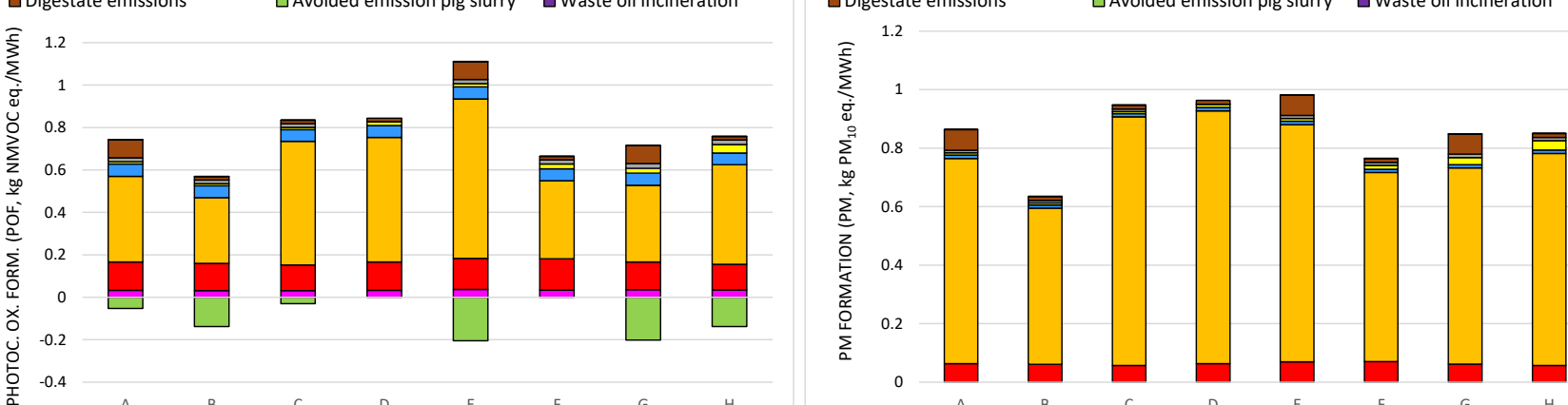

$\square$ AD methane emission

口Feedstock prod \& transp

Digestate emissions $\quad \square$ Avoided emission pig slurry aWaste oil incineration

aORC

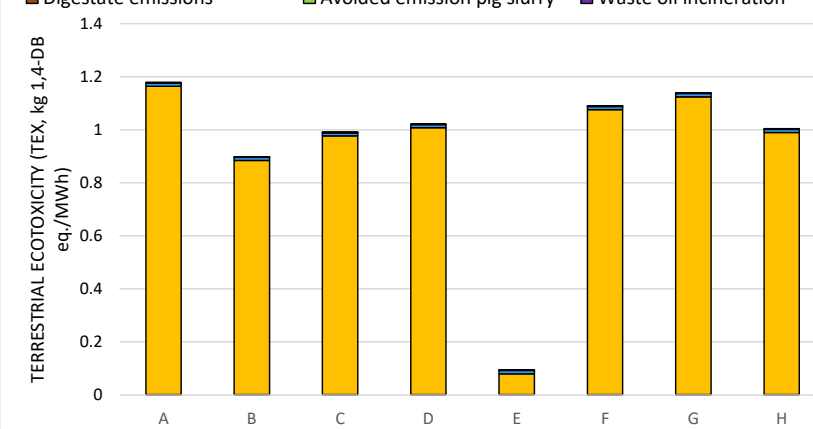


g) Photochemical oxidant formation

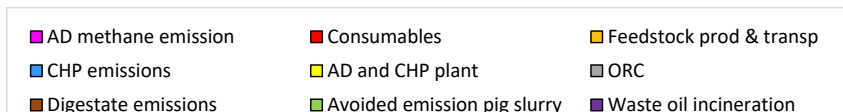

$\square$ Digestate emission

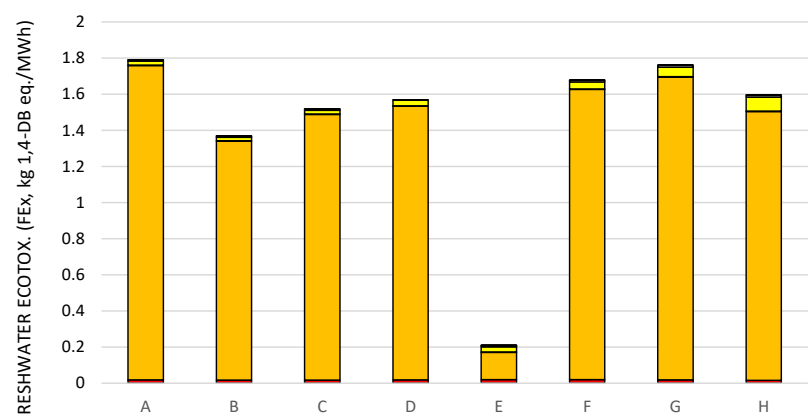

j) Freshwater eco-toxicity

$\square$ AD methane emission $\square$ Consumables $\square$ CHP emissions $\quad \square A D$ and CHP plant $\square A D$ and CHP plant $\quad \square \mathrm{ORC}$ - Waste oil incineration

h) Particulate matter formation

$\begin{array}{lll}\square \text { aD methane emission } & \square \text { Consumables } & \square \text { Feedstock prod \& transp } \\ \square C H P \text { emissions } & \square A D \text { and CHP plant } & \square \text { ORC } \\ \square \text { Digestate emissions } & \square \text { Avoided emission pig slurry } & \text { Waste oil incineration }\end{array}$

Digestate emissions $\quad \square$ Avoided emission pig slurry $\quad$ @Waste oil incineration

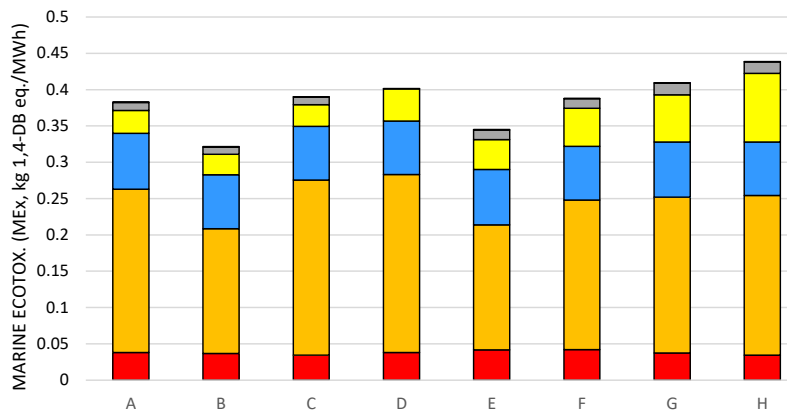

k) Marine eco-toxicity i) Terrestrial eco-toxicity

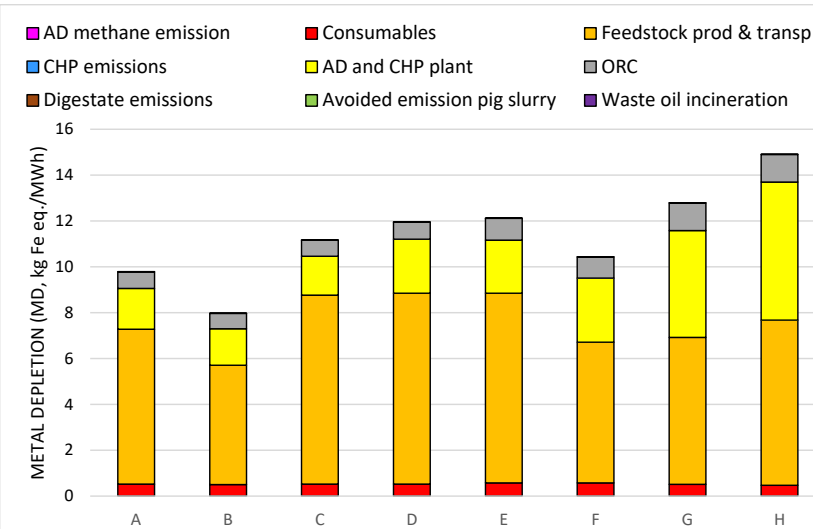

I) Metal depletion

a

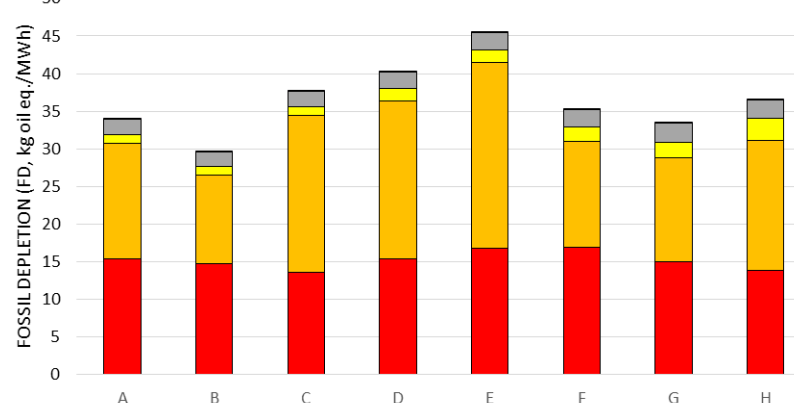

m) Fossil depletion

Figure 3. Environmental impacts of AD-CHP-ORC systems. 
For all the plants, methane emissions from the AD plant are similar $(70-80 \mathrm{~kg} \mathrm{CO}$ eq./MWh). The impact related to the manufacturing, maintenance and end-of-life disposal of the ORC installation is slightly higher for the smaller plants ( $\mathrm{G}$ and $\mathrm{H}, \sim 8 \mathrm{~kg} \mathrm{CO}_{2}$ eq./MWh) than for the bigger ones ( $\mathrm{B}$ and $\mathrm{C}, 6.5 \mathrm{~kg} \mathrm{CO}$ eq./MWh). The emissions from the $\mathrm{CHP}$ plant and management of spent engine oil are small $(<3 \%$ and $<1 \%$, respectively).

Note that carbon dioxide emissions from biogas combustion in the CHP are not considered as they are biogenic in nature.

Ozone depletion (OD): The lowest OD is found for Plant B (9.73 mg CFC-11 eq./MWh) and the highest for Plant $\mathrm{E}$ (16.42 mg CFC-11 eq./MWh). The main contributor is the feedstock production and transport and, in particular, the diesel fuel used in the machinery during field operations. This is followed by the consumables and, in particular, halons emitted in the life cycle of grid electricity used in AD (Figure 3b). The share of OD due to the feedstock ranges from 44\% (Plant $F$ fed only with maize silage) to $63 \%$ (Plant $E$ fed with triticale silage and cow slurry). Between $4 \%$ (Plants $C$, $\mathrm{D}$ and $\mathrm{E})$ to $7 \%$ (Plant $\mathrm{G}$ ) of this impact is due to the manufacturing, maintenance, use and disposal of the ORC and, in particular, the consumption of electricity.

Terrestrial acidification (TA): TA varies from 3.89 to $5.92 \mathrm{~kg} \mathrm{SO}_{2}$ eq./MWh, with Plant $\mathrm{B}$ being the best and Plant $D$ the worst system. Cereals cultivation is responsible for the large majority of the impact (85\%-94\%) for all the plants (Figure 3c). Ammonia emissions from digestate storage plays a minor role $(<3 \%)$, except for the three plants $(A, E$ and $F)$ with open storage tanks.

Freshwater and marine eutrophication (FE \& ME): These two impacts range from 21.33-47.79 g $P$ eq./MWh and 0.16-4.49 kg N eq./MWh, respectively. Plant B presents the lowest values for both categories, while Plant $\mathrm{E}$ has the highest FE and Plant $\mathrm{G}$ the largest ME. For all the plants, more than $95 \%$ of both impacts is due to cereals cultivation (Figure $3 \mathrm{~d} \& \mathrm{e}$ ).

Human toxicity $(H T)$ : There is little difference in this impact between the plants, with the values ranging from $26.14 \mathrm{~kg}$ 1,4-dichlorobenzene (DB) eq./MWh (Plant B) to $30.09 \mathrm{~kg}$ 1,4-DB eq./MWh (Plant D). The main contributor to $\mathrm{HT}(65 \%)$ is the emissions of mercury and arsenic from biogas burned in the CHP plant (Figure 3f). The rest of the impact is caused by feedstock cultivation (10$17 \%)$ and incineration of waste engine oil (10\%).

Photochemical oxidant formation (POF): The lowest POF is estimated at $0.43 \mathrm{~kg}$ non-methane volatile organic compounds (NMVOC) eq./MWh for Plant B and the highest for Plant $E(0.91 \mathrm{~kg}$ NMVOC eq.). The impact is largely due to cereals cultivation (51-70\%), followed by consumables, and electricity in particular (14-23\%) (Figure $3 \mathrm{~g}$ ). POF is reduced due the credits for the avoided methane emissions from traditional slurry storage, with Plants $B$ and $G$ benefiting the most.

Particulate matter formation (PMF): This impact is lowest for Plant B (0.63 kg PM10 eq./MWh) and highest for Plants C, D and E ( 0.95 kg PM10 eq./MWh). All the plants are primarily influenced by the cultivation of cereals and, specifically, by emissions from diesel fuels used in agricultural machinery (Figure $3 \mathrm{~h}$ ).

Terrestrial, freshwater and marine eco-toxicity (TEx, FEx, MEx): These three impacts are quite similar across the plants, except for TEx and FEx where plant $E$ has by far the lowest values $(0.09$

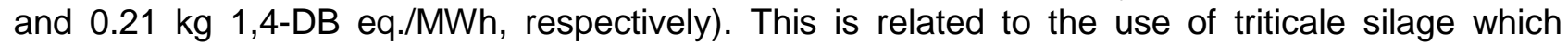
entails a lower application of pesticides than maize. The latter is the main cause of the impacts $(50-62 \%)$ for all the other plants (Figure 3i\&j). In the case of ME, the other contributors include emissions of heavy metals from biogas combustion and from the production of metals used for construction of the AD and CHP plants.

Overall, Plant A has slightly higher impacts than the remaining plants. The exception is MEx, for which plant $\mathrm{H}$ shows the worst performance (Figure 3k). 
Metal depletion (MD): Metal depletion ranges from 7.96 (Plant B) to $14.89 \mathrm{~kg}$ Fe eq./MWh (Plant $\mathrm{H})$. As can be seen in Figure $3 \mathrm{I}, \mathrm{MD}$ is mainly due to feedstock production $(48-74 \%)$ and, in particular, to the materials used for agricultural machinery. This is followed by the materials used for the AD and CHP plants (18-40\%). The role played by construction materials for the AD and CHP plants is proportionally higher for small plants ( $40 \%$ for Plant $\mathrm{H}$ and $36 \%$ for plant $\mathrm{G}$ ) than for the large $(18 \%$ for plant $A)$.

Fossil depletion (FD): As indicated in Figure $3 \mathrm{~m}$, the lowest FD is estimated for Plant B and the highest for Plant E (29.60 and $45.45 \mathrm{~kg}$ oil eq./MWh, respectively). The fuel used for cereals cultivation and the electricity for the AD plants are the major contributors to this category for all the plants. Between $5-8 \%$ of FD is due to the manufacturing, maintenance, use and disposal of the ORC plant.

\subsection{Comparison of systems with and without ORC}

As can be seen in Figure 4, implementing the ORC system reduces most impacts because of the additional electricity it generates. However, the average reductions are relatively small, ranging from $1.6 \%$ for ozone depletion to $5.8 \%$ for marine eutrophication. On the other hand, depletion of metals increases slightly with the ORC $(1.1 \%)$ while depletion of fossil resources is unaffected. For these two categories, the benefits related to the increased electricity production are offset by the impacts from the manufacture and maintenance of the ORC equipment.

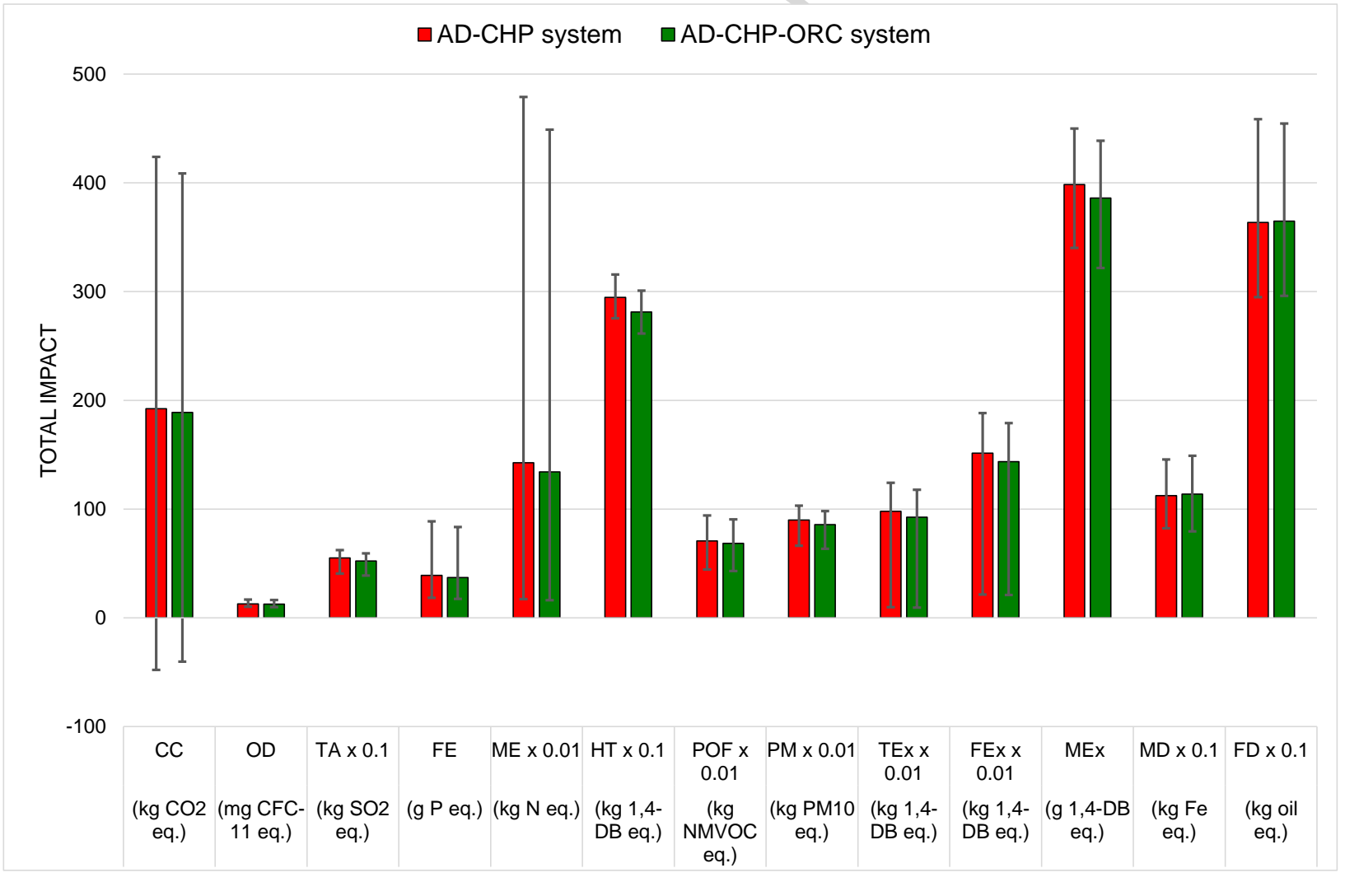

Figure 4. Environmental impacts of the systems with and without ORC.

[The impacts refer to plants A-H. All impacts are per MWh of electricity generated. The error bars represent the minimum and maximum impacts across the plants considered and the graph bars represent the average values across the plants. Impacts nomenclature: CC, climate change; OD, ozone depletion; TA, terrestrial acidification; FE, freshwater eutrophication; ME, marine eutrophication; HT, human toxicity; POF, photochemical oxidant formation; PMF, particulate matter formation; TE, terrestrial eco-toxicity; FEX, freshwater eco-toxicity; MEX, marine eco-toxicity; MD, metal depletion; FD, fossil depletion. DB, dichlorobenzene, NMVOC, non-methane volatile organic compounds.] 
Looking at the results for the individual AD-CHP-ORC plants in Table 2 and Table S1, the impacts are reduced across all the plants for nine categories. For the remaining four impacts, the following can be noticed:

- climate change decreases for five plants (1.4\%-3.6\%) but increases significantly for the remaining three plants mainly fed with animal slurry $(B, G$ and $H)$; the increase is particularly high for plant $\mathrm{H}$ (27 times) due to the high impact of the ORC installation compared to the ADCHP plant (Table S1 in the SI).

- ozone depletion also decreases for five plants (0.7\%-5\%) but increases slightly for plants $A, F$ and $\mathrm{G}$ (by $0.1 \%$ to $0.5 \%$ );

- metal depletion decreases for Plants B and C (3.4\% and 3.8\%, respectively), while it increases slightly for all other plants (1.1\%-3.8\%); and

- fossil depletion decreases for only Plants $\mathrm{C}$ and $\mathrm{E}(\sim 0.8 \%)$, while it increases slightly in all the other plants $(0.4 \%-1.5 \%)$.

The results also suggest that the reduction in impacts is higher for the bigger plants where the surplus heat available for the ORC is higher (A, C and D). For the small plants, fed mainly with animal slurry, the benefits are reduced due to the lower electricity produced by the ORC and the impacts from the construction of the ORC equipment, in particular, the micro-turbine.

Table 2. Heat map showing change in the impacts of the AD-CHP-ORC relative to the ADCHP systems.

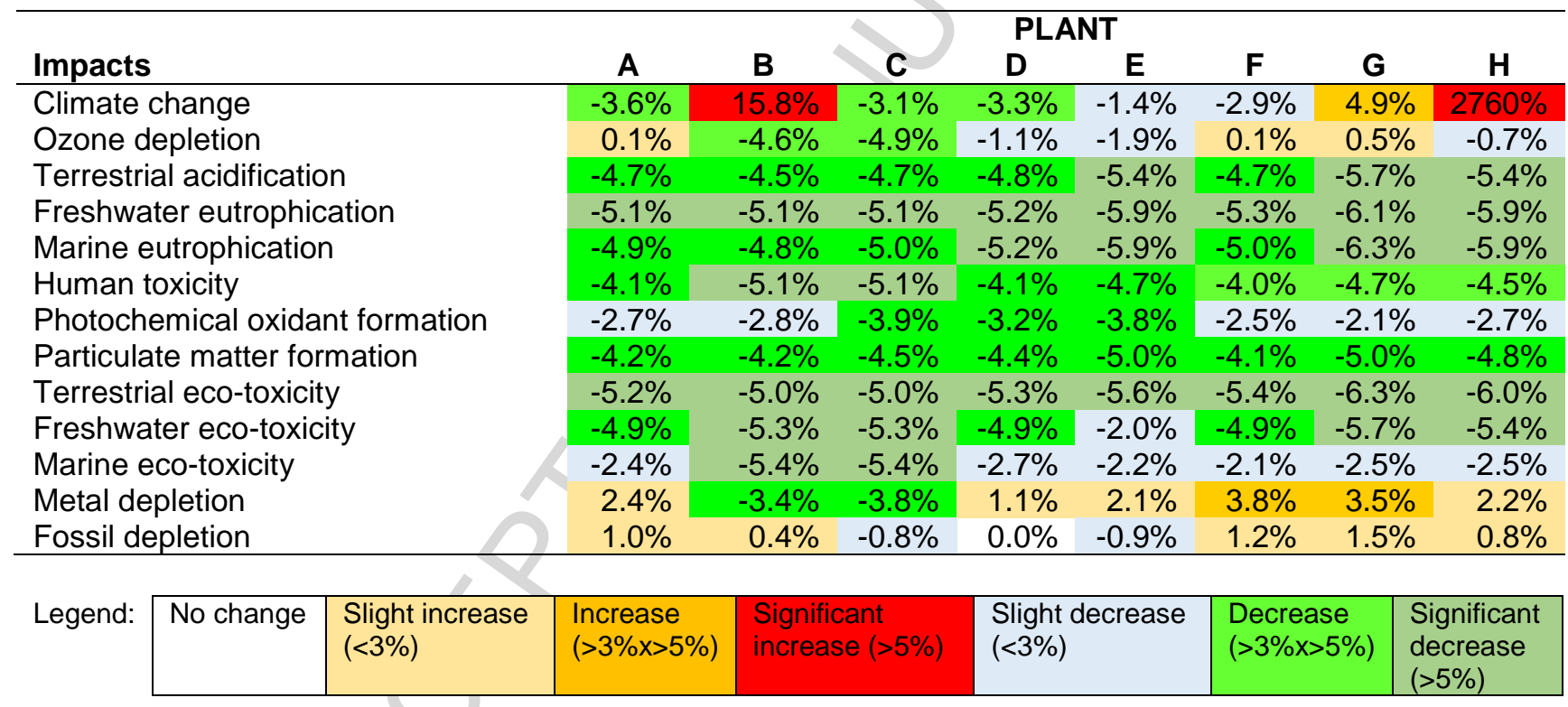

If Plants I and $\mathrm{J}$, for which the adoption of an ORC system was not suitable, are compared to Plants A-H with an ORC system (Table S1), there would be a slight change in the ranking of plants on their environmental performance. Plant I is the best option of all the AD-CHP systems, largely because it utilises slurry rather than cereal silage as feedstock. However, if the ORC system is installed in Plants $\mathrm{A}-\mathrm{H}$, then Plant B is more sustainable for human toxicity and metal depletion than Plant I due to the economies of scale. However, the latter remains environmentally superior for all the other impacts. This includes climate change which is 32 times lower than for Plant $\mathrm{B}$ (-1542 vs $47.9 \mathrm{~kg} \mathrm{CO}$ eq. $/ \mathrm{MWh}$ ). This is because the benefits from the recovery of waste heat via the ORC are not sufficient to counter the high impacts of cereal silage used in Plant $B$ relative to slurry used in Plant I. Therefore, while there are clear benefits of fitting an ORC system to an ADCHP plant, greater benefits can still be achieved by utilising waste feedstocks, such as slurry, instead of cereal silage. 


\subsection{Correlations with different parameters}

According to the above results the type of feedstock influences the impacts, with the utilisation of slurry yielding lower impacts than the use of cereal silage. These findings have also been corroborated by other authors, including Fusi et al. (2016), Lijò et al. (2017a, 2017b) and Fuchsz and Kohlheb (2015). Specifically, the use of animal slurry reduces climate change and photochemical oxidant formation, while the use of cereal silages increases all impact categories, and in particular the ones related to the emissions of $\mathrm{N}$ and $\mathrm{P}$ compounds, i.e. eutrophication and acidification (De Vries et al., 2012; Lijò et al., 2014, Whiting and Azapagic, 2014).

The economies of scale also play a role, as discussed in the previous section, affecting human toxicity and mineral and fossil depletion in particular. Similar findings were reported by Whiting and Azapagic (2014) and Bacenetti et al. (2016), who considered the influence on impacts of specific digester volume $\left(\mathrm{m}^{3}\right.$ of digester/ $\left.\mathrm{kW}\right)$. Furthermore, according to Van Stappen et al. (2016), consumption of electricity by the AD-CHP system is a key factor for ozone depletion. Other parameters that may influence the impacts include the amount of electricity generated per unit of installed capacity and the efficiency of the CHP plant.

To gauge the significance of these parameter for the impacts and find out if they could be extrapolated over the ranges to avoid the need for detailed LCA studies of each plant, their values have been plotted against each impact over the parameter ranges for the ten plants. Based on the results of a regression analysis, only the type of feed showed a significant correlation with some impact categories. These results are shown in Figures S1 and S2 in the SI for the animal slurry and cereal silage, respectively. The parameter considered for each is the specific consumption of dry matter per MWh of electricity generated. For both feed types, two scenarios have been assessed with respect to the digestate storage tanks: i) current situation with both covered and uncovered digestate storage tanks (Table 1); and ii) covered storage only, assuming that all current open tanks could be covered.

As can be seen in Figures S1 and S2, the impacts most affected by the feed are climate change, terrestrial acidification, photochemical oxidant and particular matter formation $\left(0.75>R^{2}>0.95\right)$. They decrease with increasing the specific consumption of slurry, while they go up with the consumption of silage. Overall, this correlation is stronger for animal slurry than the silage. For the other impact, the correlation is weaker $\left(R^{2}<0.75\right)$. Marine eutrophication, human toxicity, marine eco-toxicity, metal and fossil depletion are unaffected by the type of feedstock.

Therefore, these findings suggest that only four impacts could be extrapolated for the specific consumption of dry matter in each type of feedstock: climate change, terrestrial acidification, photochemical oxidant and particular matter formation. These results could be used in screening LCA studies to identify optimal plant operating regimes with respect to the feed. Given that climate change is one of the key policy drivers for AD-CHP plants, the relationships derived here could also be useful to guide policy. However, detailed LCA studies would still be needed for all other impacts not showing a strong dependency on any of the parameters. In other words, while these parameters determine the impacts, they do not follow a generic rule or relationship that would apply across different plants and each plant needs to be considered on a case-by-case basis.

\subsection{Sensitivity analysis}

In addition to the parameter discussed above, the influence on impacts of further three parameters is considered within the sensitivity analysis, one at a time:

- covered instead of open storage of digestate in Plants A, E, G, I and $\mathrm{J}$ in the AD-CHP system;

- electrical efficiency of the ORC system (Plants A-H); and

- the lifespan of the ORC system.

The first parameter has been selected due to the significance of emissions from the digestate storage for the impacts and the last two parameters are considered due to an uncertainty in the original assumptions, as discussed below. 


\subsubsection{Covered storage of digestate}

Given that much of climate change, terrestrial acidification, marine eutrophication and particulate matter formation is due to the methane and ammonia emissions from open storage of the digestate (section 3.1), this part of the sensitivity analysis considers what would happen if the digestate were stored in covered tanks. The results in Figure $\mathbf{5}$ suggest that covering the storage tanks would decrease climate change by $11 \%$ (Plant I) to three times (Plant G). The decrease in ammonia emissions would also lead to the reductions in acidification (11-44\%) and eutrophication (up to $52 \%$ ). Furthermore, particulate matter formation would decrease from $4 \%$ (Plant I) to $18 \%$ (Plant J) due to the recovery of methane and the additional electricity production. The remaining categories are either not influenced by covering the digestate storage or show slightly worse performance. The latter can be explained by the additional materials and energy needed to produce the cover for the tanks $\left(1200 \mathrm{~kg}\right.$ of synthetic rubber for a digester of $\left.500 \mathrm{~m}^{3}\right)$.

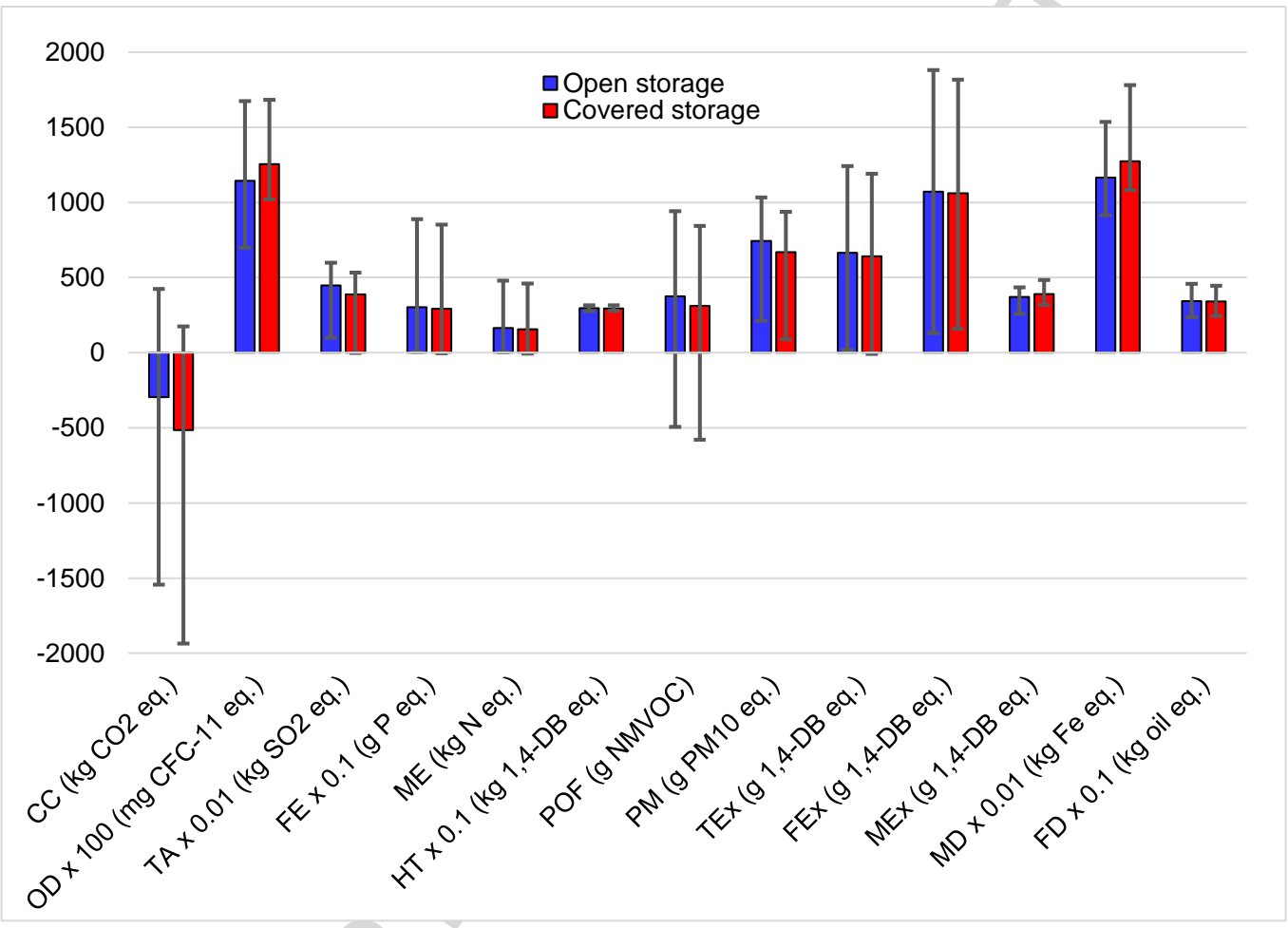

Figure 5. Environmental impacts from Plants A, E, G, I and J with open and covered storage of the digestate.

[All impacts are per MWh of electricity generated. The graph bars represent the average impacts for Plants $A, E, G, I$ and $\mathrm{J}$; the error bars show the variation in the impacts for the different plants. For the impacts nomenclature, see Figure 4 .]

\subsubsection{Electrical efficiency of the ORC plant}

The electrical efficiency of the ORC plant has been assumed at $10 \%$. Varying the efficiency between $5 \%$ and $15 \%$ has a small effect on the impacts, changing each by around $\pm 3 \%$.

\subsubsection{The lifespan of the ORC plant}

The addition of an ORC system to AD-CHP plants is not common practice yet, so their actual lifespan is unknown. In this analysis, the lifespan of 20 years has been assumed. Reducing it to 15 years would have a negligible effect on the impacts, increasing them from $0 \%$ for marine eutrophication to 3\% for metal depletion (Table S2). The latter increases the most due to the higher requirements for the construction materials for an ORC system that lasts less. The increase in climate change is negligible $(<0.5 \%)$ for all the plants, except Plant $\mathrm{H}(4 \%)$. The impact increase is lower for large than the small plants. 


\section{Conclusions}

Given the growing scarcity of primary energy resources, increasing the efficiency of energy conversion processes is one of the key challenges for optimising primary energy use. From this perspective, low-grade heat or waste heat from various processes is of an increasing interest as a secondary energy source.

This study has focused on the recovery of low-grade heat from AD-CHP systems to produce additional electricity via the ORC. To evaluate the environmental sustainability of such systems, life cycle environmental impacts of electricity generated by eight different AD-CHP-ORC systems have been estimated in comparison with the equivalent systems without heat recovery via the ORC. The results suggest that systems with ORC have lower impacts than those without it, but the average reductions are relatively small, ranging from $1.6 \%$ for ozone depletion to $5.8 \%$ for marine eutrophication. However, for the smaller plants fed mainly with animal slurry, climate change increases significantly (up to 27 times).

The results also suggest that the reduction in impacts is greater for the bigger plants where the surplus heat available for the ORC is higher. For the small plants, fed mainly with animal slurry, the benefits are reduced due to the lower electricity produced by the ORC and the impacts from the construction of the ORC equipment.

The main contributors to the impacts are the production of the cereal silage and the emissions from the digestate. Covering the storage tanks would decrease climate change by $11 \%$ to three times. The decrease of ammonia emissions would also reduce acidification (11-44\%) and eutrophication (up to $52 \%$ ). The recovery of methane and the additional electricity production would lower particulate matter formation (4-18\%). The economies of scale also play a role, affecting human toxicity and mineral and fossil depletion in particular. The impacts from the ORC plant are small and its electrical efficiency has little influence on the results.

Some of the impacts are strongly correlated with the type of the feedstock, including climate change, terrestrial acidification, photochemical oxidants and particular matter formation. They decrease with increasing the consumption of slurry per $\mathrm{MWh}$, while they go up with the consumption of silage. These correlations could be used in screening LCA studies and to guide policy.

Overall, the findings of the study suggest that the ORC could represent a viable solution for reducing the impacts of electricity from biogas. However, for technical reasons, the ORC system cannot be applied in small plants $(<150 \mathrm{~kW})$. Further effective solutions for reducing the impacts from AD-CHP systems include increasing the use of animal slurry instead of cereal silage and covering the digestate storage tanks.

When comparing small slurry-fed plants without the ORC with bigger silage-fed plants fitted with an ORC system, the former still have lower environmental impacts for nine categories; climate change is up to 32 times lower. They are only slightly worse than a bigger plant with the ORC for ozone depletion and human toxicity due to the economies of scale. Therefore, while there are clear benefits of fitting an ORC system to an AD-CHP plant, greater benefits can still be achieved by utilising waste feedstocks, such as slurry, instead of fitting an ORC to a plant using cereal silage.

\section{Nomenclature}

d number of days in month $i$ (days)

$\mathrm{EE}_{\mathrm{CHP}} \quad$ electricity produced by the CHP plant ( $\mathrm{kWh} /$ year)

$\mathrm{EE}_{\mathrm{ORC}} \quad$ electricity produced by the ORC plant (kWh/year)

i month in a year (-)

$\mathrm{k} \quad$ coefficient of thermal dispersion (proportion of thermal energy used to heat the feedstock in the digester that is lost) (\%)

$\mathrm{M}_{\mathrm{BIO}} \quad$ mass of the feedstocks in the digester ( $\mathrm{t} / \mathrm{day}$ )

$\mathrm{P}_{\mathrm{EE} \_\mathrm{CHP}} \quad$ electrical capacity of the CHP plant $(\mathrm{kW})$ 


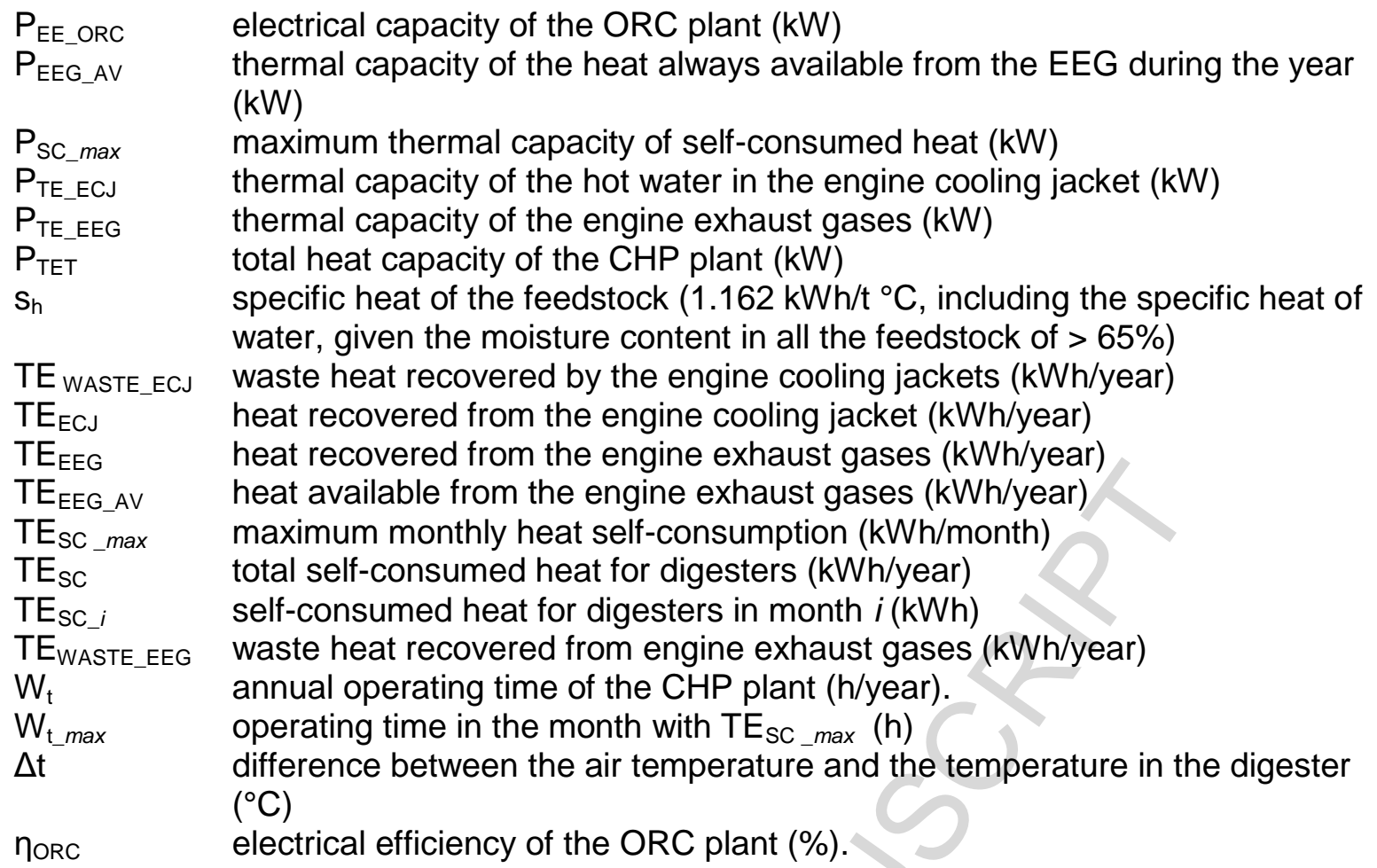

\section{Acknowledgements}

This work has been funded by the UK Engineering and Physical Sciences Research Council (EPSRC), grant no. EP/K011820/1. This funding is gratefully acknowledged.

\section{References}

Audsley, E. (1997). Harmonization of Environmental Life Cycle Assessment for Agriculture. European Commission DG VI Agriculture. Silsoe: Silsoe Research Institute.

Bacenetti J., Fusi A. (2015). The environmental burdens of maize silage production: Influence of different ensiling techniques. Anim Feed Sci. Techn., vol. 2015, 204, 88-98. doi: 10.1016/j.anifeedsci.2015.03.005.

Bacenetti J., Fusi A., Negri M., Fiala M. (2015b). Impact of cropping system and soil tillage on environmental performance of cereal silage productions. J. of Clean. Prod, vol. 86, p. 49-59. doi: 10.1016/j.jclepro.2014.08.052.

Bacenetti, J, Fiala, M. (2015). Carbon footprint of electricity from anaerobic digestion plants in Italy. Environ. Eng. \& Manag. J. 14 (7), 1495-1502.

Bacenetti, J., Duca, D., Fusi, A., Negri, M., and Fiala, M. (2015). Mitigation strategies in the agrofood sector: the anaerobic digestion of tomato puree by-products. An Italian case study. Sci. Total Environ. 526, 88-97. doi:10.1016/j. scitotenv.2015.04.069

Bini R., Di Prima M., Guercio A. 2010. Organic Rankine Cycle (ORC) in biomass plants: an

Bodria, L., Pellizzi, G., and Piccarolo, P. (2006). Il trattore e le macchine operatrici. Bologna: Ed. Edagricole.

Brentrup, F., Küsters, J., Lammel, J., and Kuhlmann, H. (2000). Methods to estimate on-field nitrogen emissions from crop production as an input to LCA studies in the agricultural sector. Int. J. Life Cycle Assess. 5, 349-357. doi:10.1007/ BF02978670.

Cellura, M., Ardente, F., and Longo, S. (2012). From the LCA of food products to the environmental assessment of protected crops districts: a case-study in the south of Italy. J. Environ. Manag. 93, 194-208. doi:10.1016/j. jenvman.2011.08.019.

Coulson, J. M., Richardson, J. F., and Sinnott, R. K. (1993). Chemical Engineering. Oxford: Butterworth-Heinemann.

De Vries, J.W, Corré, W.J.; Dooren, H.J. (2010). Environmental assessment of untreated manure use, manure digestion and co-digestion with silage maize. Wageningen UR Livestock Research. 
De Vries, J.W., Vinken, T.M.W.J., Hamelin, L., De Boer, I.J.M. (2012). Comparing environmental consequences of anaerobic mono- and co-digestion of pig manure to produce bio-energy e a life cycle perspective. Bioresour. Technol. 125, 239-48. doi: 10.1016/j.biortech.2012.08.124.

Drescher U., Brüggemann D.: Fluid Selection for the Organic Rankine Cycle (ORC) in Biomass Power and Heat Plants, Applied Thermal Engineering 2007, 27: 223-228.

Dressler D., Loewen, A., Nelles, M. (2012). Life cycle assessment of the supply and use of bioenergy: impact of regional factors on biogas production. Int. J. Life Cycle Assess. 17 (9), 1104-1115. doi:10.1007/s11367-012-0424-9

Ecoinvent (2013). Ecoinvent. Ecoinvent Database v3. Zurich; Lausanne.

European Commission (2014). $\operatorname{COM(2014)~} 15$ final. Communication from the commission to the European parliament, the council, the European economic and social committee and the committee of the regions. A policy framework for climate and energy in the period from 2020 to 2030. content/EN/TXT/PDF/?uri=CELEX:52014DC0015\&from=EN.

Fiala, M. (2012). Energia da biomasse. Santarcangelo di Romagna: Maggioli Editore.

Fuchsz, M., \& Kohlheb, N. (2015). Comparison of the environmental effects of manure-and cropbased agricultural biogas plants using life cycle analysis. Journal of Cleaner Production, 86, 6066.

Fusi, A., Bacenetti, J., Fiala, M., Azapagic, A. (2016). Life Cycle Environmental Impacts of Electricity from Biogas Produced by Anaerobic Digestion. Front. Bioeng. Biotechnol. 4:26. doi: 10.3389/fbioe.2016.00026.

German Biogas Association, 2016. Biogas sector statistics 2015-2016.

Gestore Sistema Elettrico (GSE), 2017.Rapporto statistico: Energia da fonti rinnovabili in Italia, Anno 2015. P.195.

Goedkoop, M.J., Heijungs, R., Huijbregts, M., De Schryver, A., Struijs, J., Van Zelm, R. (2009). ReCiPe 2008, a life cycle impact assessment method which comprises harmonised category indicators at the midpoint and the endpoint level, first ed. Report I: Characterisation. www.lciarecipe.net.

González-García S., Bacenetti J., Negri M., Fiala M., Arroja L. (2013). Comparative environmental performance of three different annual energy crops for biogas production in Northern Italy. J. of Clean. Prod, vol. 43, p. 71-83 doi: 10.1016/j.jclepro.2012.12.017

GSE, 2015. Statistical Report 2013 on Renewable-Energy Power Plants in Italy, published by GSE's Statistical Office, website www.gse.it.

Hahn, H., Hartmann, K., Bühle, L., Wachendorf, M. (2015). Comparative life cycle assessment of biogas plant configurations for a demand oriented biogas supply for flexible power generation. Bioresour. Technol. 179, 348-358. doi: 10.1016/j.biortech.2014.12.007.

ISO. (2006a). ISO 14040. Environmental Management - Life Cycle Assessment - Principles and Framework. Geneva: International Organization for Standardization.

ISO. (2006b). ISO 14044. Environmental Management - Life Cycle Assessment - Requirements and Guidelines. Geneva: International Organization for Standardization.

Jradi, M., Li, J., Liu, H., \& Riffat, S. (2014). Micro-scale ORC-based combined heat and power system using a novel scroll expander. International Journal of Low-Carbon Technologies, ctu012.

Lijó L., González-García S., Bacenetti J., Fiala M., Feijoo G., Lema J.M., Moreira M.T. (2014). Life Cycle Assessment of electricity production in Italy from anaerobic co-digestion of pig slurry and energy crops. Renew Energ, vol. 68, p. 625-635, doi: 10.1016/j.renene.2014.03.005.

Lijó L., González-García S., Bacenetti J., Fiala M., Feijoo G., Moreira M.T. (2014). Assuring the sustainable production of biogas from anaerobic mono-digestion. JOURNAL OF CLEANER PRODUCTION, vol. 72, p. 23-34, ISSN: 0959-6526, doi: 10.1016/j.jclepro.2014.03.022.

Lijó L., González-García S., Bacenetti J., Negri M., Fiala M., Feijoo G., Moreira M.T (2015). Environmental assessment of farm-scaled anaerobic co-digestion for bioenergy production. Waste Man., 50-59. DOI: 10.1016/j.wasman.2015.03.043.

Lijó, L., González-García, S., Bacenetti, J., \& Moreira, M. T. (2017). The environmental effect of substituting energy crops for food waste as feedstock for biogas production. Energy. doi.org/10.1016/j.energy.2017.04.137. 
Lijó, L., Lorenzo-Toja, Y., González-García, S., Bacenetti, J., Negri, M., \& Moreira, M. T. (2017). Eco-efficiency assessment of farm-scaled biogas plants. Bioresource Technology, 237, 146155.

Margni, M., Rossier, D., Crettaz, P., and Jolliet, O. (2002). Life cycle impact assessment of pesticides on human health and ecosystems. Agric. Ecosyst. Environ. 93, 379-392. doi:10.1016/S0167-8809(01)00336-X.

Mauky, E., Jacobi, H.F., Liebetrau, J., Nelles, M., 2015. Flexible biogas production for demanddriven energy supply - Feeding strategies and types of substrates. Bioresour. Technol. 178, 262-269. doi:10.1016/j.biortech.2014.08.123.

Negri M, Bacenetti J, Manfredini A., Lovarelli D., Fiala M., Maggiore T.M., Bocchi S. (2014a). Evaluation of methane production from maize silage by harvest of different plant portions. Biomass Bioen, vol. 67, p. 339-346 doi: 10.1016/j.biombioe.2014.05.016.

Negri, M., Bacenetti, J., Brambilla, M., Manfredini, A., Cantore, C., and Bocchi, S. (2014b). Biomethane production from different crop systems of cereals in Northern Italy. Biomass Bioen 63, 321-329. doi:10.1016/j. biombioe.2014.01.041.

Nemecek, T., and Kägi, T. (2007). Life Cycle Inventories of Agricultural Production Systems. Ecoinvent Report Version 2.0, Vol. 15. Zurich: Swiss Centre for LCl, ART.

NERI. (2010). Emissions from Decentralized CHP Plants. 113. http://www2.dmu.dk/pub/FR786.pdf.

Obi, J. B. (2015). State of Art on ORC Applications for Waste Heat Recovery and Microcogeneration for Installations up to 100kWe. Energy Procedia, 82, 994-1001.

overview on different applications. Turboden srl. Brescia (Italy) Available at: http://www.turboden.eu/en/public/downloads/Scheda\%20Biomassa\%20CHP\%20Split\%20\%20ING.pdf.

Quoilin, S., Van Den Broek, M., Declaye, S., Dewallef, P., \& Lemort, V. (2013). Techno-economic survey of Organic Rankine Cycle (ORC) systems. Renewable and Sustainable Energy Reviews, 22, 168-186.

Schulz W, Heitmann S, Hartmann D, Manske S, Peters ES, Risse S. Utilization of heat excess from agricultural biogas plants. Bremen Germany: Bremer Energie Institut, Universität Bremen, Institut für Umweltverfahrenstechnik; 2007.

Smolen S., Schröder H. (2007). Thermodynamic and economical analysis of ORC application for waste heat use from a biogas plant farm (Energetische und wirtschaftliche Untersuchung der Einsatzmöglichkeiten eines ORC- Prozesses zur Abwärmenutzung in einem Biogasanlagenpark), 1. International Conference: "Low- Temperature and Waste Heat Use in Communal and Industrial Energy Supply Systems, Theory and Practice" ("Niedertemperatur und Abwärmenutzung in kommunalen und industriellen Energieversorgungssystemen, Theorie und Praxis"), Conference Proceedings, JRMayer Institut für Energietechnik, Hochschule Bremen, Germany, November 2007.

Styles, D., Dominguez, E. M., \& Chadwick, D. (2016). Environmental balance of the UK biogas sector: An evaluation by consequential life cycle assessment. Science of the Total Environment, 560, 241-253.

Vaja I., Gambarotta A. (2010). Internal combustion engine (ICE) bottoming with organic Rankine cycles (ORCs). Energy, 35(2), 1084-1093.

Van Stappen, F., Mathot, M., Decruyenaere, V., Loriers, A., Delcour, A., Planchon, V., J.P. Goffard \& Stilmant, D. (2016). Consequential environmental life cycle assessment of a farm-scale biogas plant. Journal of environmental management, 175, 20-32.

Weidema, B.P., Bauer. C., Hischier, R., Mutel, C., Nemecek, T., Reinhard, J., Vadenbo, C.O., Wernet, G., 2013. Overview and methodology. Data quality guideline for the ecoinvent database version 3. Ecoinvent Report 1(v3). St. Gallen: The Ecoinvent Centre.

Whiting, A., and Azapagic, A. (2014). Life cycle environmental impacts of generating electricity and heat from biogas produced by anaerobic digestion. Energy 70, 181-193. doi:10.1016/j.energy.2014. 


\section{ACCEPTED MANUSCRIPT}

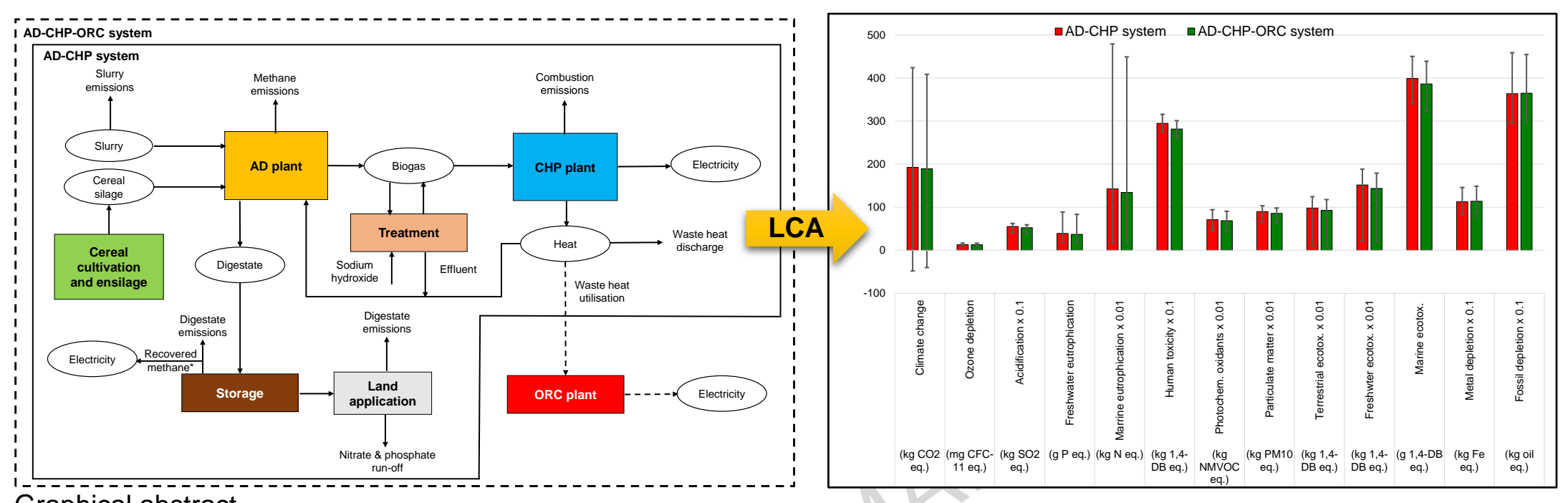

Graphical abstract 
Highlights

- Environmental impacts have been estimated for ten real anaerobic digestion plants.

- Plants with organic Rankine cycle (ORC) have lower impacts than those without it.

- The average reductions in impacts are small (1.6-5.8\%).

- For smaller plants with animal slurry, climate change increases by 27 times with ORC.

- Greater benefits can be achieved by using animal slurry than ORC in silage plants. 